NBER WORKING PAPER SERIES

\title{
SCHOOLING EXTERNALITIES, TECHNOLOGY AND PRODUCTIVITY: THEORY AND EVIDENCE FROM U.S. STATES
}

\author{
Susana Iranzo \\ Giovanni Peri \\ Working Paper 12440 \\ http://www.nber.org/papers/w12440
NATIONAL BUREAU OF ECONOMIC RESEARCH
1050 Massachusetts Avenue
Cambridge, MA 02138

August 2006

We are very grateful to Daron Acemoglu and two anonymous referees for extremely helpful suggestions. We thank Jordan Rappoport for kindly sharing with us the data on population and geographical coordinates of U.S. counties. We thank Antonio Ciccone and Benjamin Mandel for extremely helpful comments. Seminar participants at UC Davis, University of Munich, RSSS at the Australian National University, Victoria University of Wellington and Monash University also provided useful comments. The views expressed herein are those of the author(s) and do not necessarily reflect the views of the National Bureau of Economic Research.

(C) 2006 by Susana Iranzo and Giovanni Peri. All rights reserved. Short sections of text, not to exceed two paragraphs, may be quoted without explicit permission provided that full credit, including @ notice, is given to the source. 
Schooling Externalities, Technology and Productivity: Theory and Evidence from U.S. States Susana Iranzo and Giovanni Peri

NBER Working Paper No. 12440

August 2006

JEL No. J24,J31,O41,R11

\begin{abstract}
$\underline{\text { ABSTRACT }}$
The recent literature on local schooling externalities in the U.S. is rather mixed: positive external effects of average education levels are hardly to be found but, in contrast, positive externalities from the share of college graduates can often be identified. This paper proposes a simple model to reconcile this mixed evidence. The key idea is that advanced technologies are complementary to highly educated workers, as opposed to traditional technologies which are complementary to less educated workers. Our calibrated model predicts that workers with high school education or less are employed in the traditional sector, while more educated workers are employed in the advanced sector. As the advanced sector is associated with the production of differentiated goods and services this generates a positive pecuniary externality (positive TFP effect) of college educated workers. By contrast, as no externalities are associated with the traditional technology, high school education only increases private returns. The model predictions are tested using data on U.S. states. We use compulsory attendance and child labor laws, push-driven immigration of highly educated workers and the location of Land Grant colleges as instruments for schooling attainments of workers in different states. The empirical estimates confirm that an increase in college education, but not an increase in high school education, had significant positive production externalities in U.S. states during the period 1960-2000.
\end{abstract}

Susana Iranzo

The University of Sydney

Department of Economics

Sydney, NSW 2006 AUSTRALIA

s.iranzo@econ.usyd.edu.au

Giovanni Peri

Department of Economics

University of California, Davis

One Shields Avenue

Davis, CA 95616

and NBER

gperi@ucdavis.edu 


\section{Introduction}

Schooling is a valuable private investment as it increases the returns to hours worked of individuals. Moreover, as highly educated workers promote the development and adoption of better technologies, schooling may have large positive effects (externalities) on the productivity of all factors (total factor productivity or TFP). The crosscountry empirical evidence based on development accounting methods (e.g. Hall and Jones, 1999) identifies very significant positive correlations between measures of average schooling and measures of TFP across countries. Similarly, the growth literature has found positive effects of higher average schooling on growth (Temple, 1999 and de la Fuente and Domenech, 2001, 2006). However, cross-country empirical analysis is unlikely to identify what part of the correlation between human capital and TFP is the result of an externality and what part is due to common determinants such as institutions and social infrastructures. This is mainly because it is very hard to find a genuinely exogenous shift of schooling levels across countries and to track its effects on TFP in a cross-country analysis. On the other hand, the empirical research based on state or city data within the

U.S. that uses credibly exogenous instruments for the variation of schooling (such as schooling laws, presence of public colleges or demographic structure) shows mixed results on the external effects of schooling. Moretti (2004) finds large TFP effects of an increase in the share of college-graduates in US cities, while Acemoglu and Angrist (2001) and Ciccone and Peri (2006) do not find any significant TFP effect of increased average schooling across U.S. cities and states.

Beginning with Rauch (1993), the framework traditionally adopted to analyze the external effects of schooling on TFP considers average schooling as a sufficient statistic to evaluate human capital's private and external returns. This strategy, however, neglects two well-established facts highlighted in the literature on cross-country income differences (Caselli and Coleman, 2006) and the literature on technological adoption and growth (Acemoglu 1998, 2002 and Acemoglu and Zilibotti 2001). First, workers with different educational levels are not perfect substitutes in production and hence the relative wages of college and high school educated workers are affected by their relative supply (e.g. Katz and Murphy, 1992, Angrist, 1995 or Ciccone and Peri 2005). As a consequence, it seems appropriate to model two factors of production, skilled and unskilled workers, as imperfectly substitutable. Second, the presence of highly skilled workers seems to encourage the adoption of skill-complementary (or skill-biased) technologies. The 1980's and the 1990's in the U.S. witnessed a substantial increase in the college-high school wage premium as well as an increase in their relative supply (Katz and Murphy, 1992, Autor, Katz and Krueger 1998, Autor, Katz and Kearny, 2007). Furthermore, the relative wages of highly educated workers and their relative supply was much higher in rich (developed) countries in the year 2000 than in poor (developing) countries (Caselli and Coleman, 2002, 2006). These facts are consistent with systematic skill-biased technological adoption in economies with higher shares of educated workers (Acemoglu 1998, 2002). As a consequence we allow different technologies to have different degrees of complementarities 
to skills so that less educated and highly educated workers adopt different (specific) technologies to maximize their productivity.

This paper revisits the issue of schooling externalities taking into account the two above mentioned facts. We estimate the external effect of schooling using U.S. data explicitly accounting for imperfectly substitutable skill groups and skill-specific technologies. The novel contributions of the paper are three-fold: First, we introduce a model of (two) regional open economies representing U.S. states that differ in their distribution of schooling but share a common technological menu. We distinguish two types of technologies: one complementary to highly educated workers and another complementary to less educated. A supply-driven increase in highly educated workers in one state produces skill-biased technological adoption and positive external effects on TFP in that state. Second, using the model, we simulate the effects of an increase in high school education vis-a-vis an increase in college education. These two shifts have quantitatively very different impacts on productivity, with only college education having a sizeable external effect. Third, we test the model on data for U.S. states for the period 1960-2000 using the method developed in Ciccone and Peri (2006). An important feature of our empirical approach is that we can construct exogenous shifters of the years of high school per worker and the years of college education per worker that we use as instruments. On the one hand, compulsory schooling laws, in place between 1920 and 1970 and introduced at different times in different states (see Acemoglu and Angrist, 2001), provide an exogenous shifter of the years of high school per worker across states. On the other hand, a measure based on the push-driven immigration of highly educated foreign-born to U.S. states and an index of the proximity of a state's population to land grant colleges provide reasonably good instruments for the state-variation of years of college per worker. Reconciling previous evidence (Moretti 2004, Acemoglu and Angrist, 2001 and Ciccone and Peri, 2006) and in accordance with the simulated predictions of the model, we estimate that one extra year of college per worker increases the state's TFP by a very significant 6-9\% while one extra year of high school per worker increases the state's TFP by an insignificant $0-1 \%$.

The rest of the paper is organized as follows. Section 2 describes the model and analytically derives the equilibrium conditions for the cases of non tradeable and tradeable goods among states. Section 3 uses the calibrated model to simulate the external (TFP) effects of an increase in schooling due to increased high school education and an equivalent increase in schooling achieved via college education. Section 4 uses the constant composition approach developed in Ciccone and Peri (2006) to empirically estimate the effects of increased schooling on U.S. state-level data for the period 1960-2000. Section 5 provides concluding remarks.

\section{$2 \quad$ A Model of Skills and Technology Adoption}

Our model combines certain elements of Yeaple (2005) in a framework similar to that developed in Acemoglu (1998, 2002) and Acemoglu and Zilibotti (2001). We consider two open economies, representing U.S. states, 
that produce two goods. The states have access to the same technological menu and have identical tastes. We only allow them to differ in the distribution of the educational attainments of their workers, which can change due to specific events, such as schooling laws and immigration, among others. Unlike Acemoglu (2002) and Acemoglu and Zilibotti (2001) who model directed technological change, we do not try to explain the creation of new technologies but rather consider a fixed, exogenous and common array of technologies. Yet, the differences in the schooling distribution across states will affect the combination of these technologies and thus the states' sectorial composition. Our purpose is to analyze the external effects of an increase in the educational attainments in a state on its TFP. In order to develop an intuition for the sources of the externalities we present first a benchmark model with no externalities (Section 2.2) and then modify it with the introduction of a sector that produces a differentiated good and generates pecuniary externalities. We consider the cases in which the differentiated goods are non-tradeable local services (Section 2.3) and the case in which they are tradeable but subject to trade or transport costs (Section 2.4). The main question we want to answer is what are the external returns accruing to a state from an increase in the schooling level of its workers? In particular, are there external returns from increasing its college education and/or from increasing its high school education?

\subsection{Basic Framework}

Consider the economy of a state that produces two different and imperfectly substitutable goods: $Y$ and $X$. There is a mass of agents that for simplicity we standardize to one in each state. As a consumer, each agent receives one unit of utility from consuming the composite good $C$ described by the following CES aggregator:

$$
C=\left[(1-\beta) Y^{\frac{\theta-1}{\theta}}+\beta X^{\frac{\theta-1}{\theta}}\right]^{\frac{\theta}{\theta-1}} \quad \theta>1
$$

The parameter $\theta$ measures the elasticity of substitution between goods $Y$ and $X$. Taking good $Y$ as the numeraire and denoting with $P_{X}$ the price of good $X$, the demands for goods $Y$ and $X$ in the state are respectively:

$$
X=\beta^{\theta} \frac{E}{P}\left(\frac{P_{X}}{P}\right)^{-\theta} \quad Y=(1-\beta)^{\theta} \frac{E}{P}\left(\frac{1}{P}\right)^{-\theta}
$$

where $P=\left[\beta^{\theta} P_{X}^{1-\theta}+(1-\beta)^{\theta}\right]^{\frac{1}{1-\theta}}$ is the overall price index and $E$ is total expenditure on both goods. The share of aggregate expenditure devoted to the purchase of good $X$ is given by:

$$
s\left(P_{X}\right)=\frac{\beta^{\theta} P_{X}^{1-\theta}}{\beta^{\theta} P_{X}^{1-\theta}+(1-\beta)^{\theta}}
$$

As workers, the agents differ in their skills which are measured by years of schooling. ${ }^{1}$ We index the education

\footnotetext{
${ }^{1}$ Hereafter, with a little abuse of terminology, we will use the terms skills, education and schooling interchangeably.
} 
of a worker with the continuous variable $Z \in[0,1]$ and we standardize the highest level of education, a Ph.D. degree, to 1 . Hence, $Z=1$ corresponds to 20 years of schooling, the normal time to achieve a Ph.D., while high school graduation (achieved after 12 years in school) and college graduation (obtained after 16 years of schooling) correspond to $Z=0.6$ and $Z=0.8$, respectively. The distribution of workers' education in the state is described by the cumulative density function $G(Z)$ and we define $W(Z)$ as the wage, in units of the numeraire, paid to a worker with education $Z$.

Goods $Y$ and $X$ are produced using different technologies and labor is the only factor of production. Workers of any educational level can produce either of the two goods. We assume that the productivity of a worker increases with her education in both sectors but it increases more rapidly in the production of good $X$. Because of the complementarity of its technology with highly educated workers we will refer to sector $X$ as the advanced or "high-tech" sector, whereas $Y$ is the "traditional" sector. Consistent with these assumptions, productivity as a function of schooling can be expressed by the following functions:

$$
A_{X}(Z)=\exp \left(g_{X} Z\right) \quad A_{Y}(Z)=\exp \left(g_{Y} Z\right) \quad \text { with } g_{X}>g_{Y}>0
$$

As mentioned above we are not interested in explaining technological creation here and thus the production functions $A_{Y}$ and $A_{X}$ (or, more specifically, the parameters $g_{Y}$ and $g_{X}$ ) are assumed to be exogenous and common to both states. Finally, as labor is the only input, the aggregate income of workers expressed in units of the numeraire equals the aggregate expenditure on goods:

$$
E=\int_{0}^{1} W(Z) d G(z)
$$

\subsection{Benchmark Model with No Externalities}

We begin by analyzing the model when both $X$ and $Y$ are homogeneous goods produced by perfectly competitive firms using different technologies. For the moment, we will assume no trade between states and so we should think of $Y$ and $X$ as locally consumed services. Since production and consumption of each good in a given state coincide, their relative price is determined within the internal market. Perfect competition within each sector ensures that prices are equal to unit costs. This implies:

$$
\begin{aligned}
& 1=P_{Y}=\widehat{W}_{Y}=W_{Y}(Z) / \exp \left(g_{Y} Z\right) \\
& P_{X}=\widehat{W}_{X}=W_{X}(Z) / \exp \left(g_{X} Z\right)
\end{aligned}
$$

$\widehat{W}_{Y}$ and $\widehat{W}_{X}$ represent the wages per unit of effective labor in each sector and recall that good $Y$ is the numeraire. In a perfectly competitive labor market, the wage schedule adjusts to equalize the unit cost of all firms using the 
same technology. Moreover, workers choose to work in the sector where they are paid the highest wage. Since both goods must be produced in the state and highly educated workers have a comparative advantage to use the technology of sector $X$, there will be a threshold value $Z=\bar{Z}$, satisfying the condition $\widehat{W}_{X}=\exp \left[\left(g_{Y}-g_{X}\right) \bar{Z}\right]$ such that workers with education $Z<\bar{Z}$ choose to work in sector $Y$ while workers with $Z>\bar{Z}$ work in sector $X$. Using this fact, the wage schedule can be expressed as:

$$
W(Z)=\left\{\begin{array}{c}
\exp \left(g_{Y} Z\right) \text { if } 0 \leq Z \leq \bar{Z} \\
\widehat{W}_{X} \exp \left(g_{X} Z\right) \text { if } \bar{Z}<Z \leq 1
\end{array}\right.
$$

The equilibrium allocation of workers and their wages is thus fully specified once we find the threshold value $\bar{Z}$. Figure 1 plots the wage schedule, $\ln ($ Wage $)$, against education $Z$. For educational levels lower than $\bar{Z}$, workers receive higher wages working in sector $Y$, while for $Z>\bar{Z}$, workers receive higher wages in sector $X$. The relevant $(\log )$ wage schedule is represented by the bold line whose gradient (corresponding to returns to schooling) increases when moving from the low-tech to the high-tech sector. Notice that for each census year between 1970 and 2000 the empirical log-wage schedule for US workers had exactly the shape presented in Figure 1. The value of $\bar{Z}$ was in the vicinity of 12 years of schooling. This is shown in Panel 1 and will be discussed in greater detail in section 3.1 and in Appendix 2 below.

The average wage in each state equals the per capita income and because of the standardization of the employment mass to 1 , it also equals the aggregate income:

$$
E=\bar{W}=\int_{0}^{\bar{Z}} \exp \left(g_{Y} Z\right) d G(Z)+\widehat{W}_{X} \int_{\bar{Z}}^{1} \exp \left(g_{X} Z\right) d G(Z)
$$

All the endogenous variables of the model are a function of the cut-off level $\bar{Z}$ which, in turn, can be pinned down using the market clearing conditions. In a closed economy market clearing implies that the demand for each good in a given state equals its supply. As individuals spend a share $s\left(P_{X}\right)$ of their income, $\bar{W}$, on good $X$ the market clearing condition for that good is: ${ }^{2}$

$$
\frac{s\left(P_{X}\right) \bar{W}}{P_{X}}=\int_{\bar{Z}}^{1} \exp \left(g_{X} Z\right) d G(Z)
$$

Substituting (3), (8) and the fact that $P_{X}=\widehat{W}_{X}=\exp \left(g_{Y}-g_{X}\right) \bar{Z}$ into (9) we obtain the following simple

\footnotetext{
${ }^{2}$ Walras' law ensures equilibrium in the market for $Y$ as well.
} 
equilibrium condition that identifies the cut-off value $\bar{Z}$ :

$$
\int_{0}^{\bar{Z}} \exp \left(g_{Y} Z\right) d G(Z)-\left(\frac{1-\beta}{\beta}\right)^{\theta} \exp \left[\theta\left(g_{Y}-g_{X}\right) \bar{Z}\right]\left(\int_{\bar{Z}}^{1} \exp \left(g_{X} Z\right) d G(Z)\right)=0
$$

This model can easily be compared with the standard two-skill model used in Acemoglu (2002) or Caselli and Coleman (2006). Let us define $L=\int_{0}^{\bar{Z}} d G(Z)$ as the total employment of low educated workers (employed in sector $Y$ ) and $H=1-L=\int \frac{1}{Z} d G(Z)$ as the total employment of highly educated workers (employed in sector $X$ ). The average productivity of each group is $\bar{A}^{L}=\left[\int_{0}^{\bar{Z}} \exp \left(g_{Y} Z\right) d G(Z)\right] / L$ and $\bar{A}^{H}=\left[\int \frac{1}{Z} \exp \left(g_{X} Z\right) d G(Z)\right] / H$. Accordingly, the average wages for low and highly educated workers are $\bar{W}^{L}=\bar{A}^{L}$ and $\bar{W}^{H}=\widehat{W}_{X} \bar{A}^{H}$, respectively. Using this notation, condition (10) can be re-written as the familiar labor market equilibrium condition for a CES production function:

$$
\frac{\bar{W}^{H}}{\bar{W}^{L}}=\frac{\beta}{1-\beta}\left(\frac{\bar{A}^{H}}{\bar{A}^{L}}\right)^{\frac{\theta-1}{\theta}}\left(\frac{H}{L}\right)^{-\frac{1}{\theta}}
$$

Equation (11), which also appears in Acemoglu (2002), shows that the average relative wage (i.e. the average skill premium) depends on the relative supply of skills and their average relative productivity. The relative effective wage, which in this model equals the relative price of $X$, is given by:

$$
P_{X}=\frac{\widehat{W}_{X}}{\widehat{W}_{Y}}=\widehat{W}_{X}=\frac{\beta}{1-\beta}\left(\frac{\bar{A}^{H}}{\bar{A}^{L}} \frac{H}{L}\right)^{-\frac{1}{\theta}}
$$

The distribution of workers between the groups of low and highly-educated (that is, below and above $\bar{Z}$ ) and within each group, together with the parameters $g_{Y}$ and $g_{X}$ determine the average productivity of each group and the supply of effective skills $\bar{A}^{H} H$ and $\bar{A}^{L} L$. Given the constant returns to scale assumption embedded in (1) and the assumption that each worker is paid the value of her marginal product, an increase in schooling will not generate any externalities. As the simulations in section 3.1 will show, any change in the skill distribution $G(Z)$ that increases the supply of effective high skills, $\bar{A}^{H} H$, (such as an improvement in workers' tertiary school attainments) or the supply of effective low skills, $\bar{A}^{L} L$, (such as an increase in workers' secondary school attainments) would result in a total effect on production equal to its private effect. That is, the extra-output produced is fully appropriated by the workers experiencing the increase in skills and there is no external effect on the rest of the economy. ${ }^{3}$ Finally, notice that for any given distribution of skills, an increase in $g_{X}$ relative to $g_{Y}$ represents what Acemoglu (2002) and Acemoglu and Zilibotti (2001) call skill-biased technological change

\footnotetext{
${ }^{3}$ For example, the changes in wages induced by an increase in highly educated workers, namely the decrease in the wage of other high-skill workers and the increase in the wage of low-skill workers, cancel out entirely due to the constant return to scale property of the production function.
} 
(as it implies an increase in $\bar{A}^{H}$ relative to $\left.\bar{A}^{L}\right)^{4}$. For $\theta>1$, such change will cause an increase in the skill premium as well as an increase in the dispersion of wages within the group of highly educated workers.

\subsection{Monopolistic Competition and Externalities}

In order to obtain externalities from schooling we need to depart from the constant returns to scale and perfect competition assumptions. An easy way to do this is to assume that the high tech sector produces a differentiated good and operates in monopolistic competition. ${ }^{5}$ The love of variety embedded in the consumer's preferences produces an effect from an increase in highly educated workers analogous to a positive TFP effect.

Good $Y$ is still a homogeneous good produced under constant returns to scale while good $X$ is a differentiated good described by the following CES aggregator:

$$
X=\left(\int_{0}^{N} x(v)^{\frac{\sigma-1}{\sigma}} d v\right)^{\frac{\sigma}{\sigma-1}} \quad \sigma>\theta>1
$$

where $v \in[0, N]$ is an index denoting the different varieties and $\sigma$ is the elasticity of substitution between varieties of $X$. We assume the varieties to be closer substitutes for each other than they are with the homogenous good $Y$. Defining $p(v)$ as the price of variety $v$, the unit-price of the composite good $X$ is:

$$
P_{X}=\left[\int_{0}^{N} p(v)^{1-\sigma} d v\right]^{\frac{1}{1-\sigma}}
$$

The demand for each variety $v$ is given by:

$$
x(v)=\left(\frac{s\left(P_{X}\right) E}{P_{X}}\right)\left(\frac{p(v)}{P_{X}}\right)^{-\sigma}
$$

Each individual variety of good $X$ is produced using a common technology that requires a fixed cost $F_{X}$ in the form of output that cannot be sold. This can be considered a research/start-up cost to develop the variety $v$. Each firm is the sole producer of a distinct variety and there is free entry in sector $X$. The productivity, in units of output, of a worker with education $Z$ is still given by $A_{Y}(Z)=\exp \left(g_{Y} Z\right)$ and $A_{X}(Z)=\exp \left(g_{X} Z\right)$, with $g_{X}>g_{Y}$, and so the unit (labor) costs or "effective wages" are like those in (6). Similar to the previous section, there is a threshold value $Z=\bar{Z}$, satisfying $\widehat{W}_{X}=\exp \left(g_{Y}-g_{X}\right) \bar{Z}$, such that workers with skills $Z<\bar{Z}$ choose to work in sector $Y$, and workers with $Z>\bar{Z}$ choose to work in sector $X$. Thus, the wage schedule and

\footnotetext{
${ }^{4}$ To be exact a change in $g_{X}$ changes also the equilibrium value of $\bar{Z}$ and hence indirectly the amount of effective skills of each group. In our simulations the effects of changes in parameter values on $\bar{Z}$ are not very significant.

${ }^{5}$ An alternative way to introduce externalities while maintaining perfect competition in both sectors is to interpret good $C$ as a final good produced using the intermediates $X$ and $Y$, and allow in the production function in (1) a TFP term depending on $\bar{A}^{H} H$ . Such term would capture learning or matching externalities in the local economy.
} 
average wage are still given by (7) and (8), respectively.

Profit-maximization and free entry in sector $X$ imply mark-up pricing and a scale of production $x(v)$ proportional to the fixed cost:

$$
p(v)=\frac{\sigma}{\sigma-1} \widehat{W}_{X} \quad x(v)=(\sigma-1) F_{X} \text { for } v \in[0, N]
$$

At the symmetric equilibrium the price and the quantity produced by each firm are identical. Aggregating over varieties we obtain the price index for the composite good:

$$
P_{X}=N^{\frac{1}{1-\sigma}}\left(\frac{\sigma}{\sigma-1}\right) \widehat{W}_{X}
$$

where $N$ is the number of varieties of good $X$ (as well as the number of firms producing them):

$$
N=\frac{1}{\sigma F_{X}} \int_{\bar{Z}}^{1} \exp \left(g_{X} Z\right) d G(Z)
$$

Again, we can use the market clearing conditions for each variety $v$ of good $X$ to pin down the cut-off level $\bar{Z}:$

$$
\frac{s\left(P_{X}\right) \bar{W}}{N}=x(v) p(v) \quad v \in[0, N]
$$

Substituting the equilibrium values of $x(v), p(v), N$ and $\bar{W}$ and using the notation introduced above for the effective supply of low and highly educated workers, $\bar{A}^{L} L$ and $\bar{A}^{H} H$, equation (19) can be rewritten as:

$$
s\left(P_{X}\right) \bar{A}^{L} L=\left[1-s\left(P_{X}\right)\right] \widehat{W}_{X} \bar{A}^{H} H
$$

Moreover, using (3), (17) and (18) we can derive the relative effective wage which now amounts to:

$$
\frac{\widehat{W}_{X}}{\widehat{W}_{Y}}=\widehat{W}_{X}=\Phi\left(\frac{\beta}{1-\beta}\right)\left(\frac{\bar{A}^{H}}{\bar{A}^{L}} \frac{H}{L}\right)^{-\frac{1}{\theta}}\left(\bar{A}^{H} H\right)^{\frac{\theta-1}{\theta(\sigma-1)}}
$$

with $\Phi=\left(\frac{\sigma-1}{\sigma}\right)^{\frac{\theta-1}{\theta}}\left(\frac{1}{\sigma F_{X}}\right)^{\frac{\theta-1}{\theta(\sigma-1)}}$. The expression in (21) differs from (12) by the constant $\Phi$ and the term $\left(\bar{A}^{H} H\right)^{\frac{\theta-1}{\theta(\sigma-1)}}$. Now an increase in the effective supply of highly educated workers, $\bar{A}^{H} H$, say due to an increase in schooling attainments of workers above $\bar{Z}$, not only has the (negative) neoclassical supply effect on wages captured by the term $\left(\frac{\bar{A}^{H}}{\bar{A}^{L}} \frac{H}{L}\right)^{-\frac{1}{\theta}}$ but also a positive "productivity" effect captured by the term $\left(\bar{A}^{H} H\right)^{\frac{\theta-1}{\theta(\sigma-1)}}$. Furthermore, substituting (21) and (18) into (17) we can obtain an expression for the price of the composite $\operatorname{good} X$ : 


$$
P_{X}=\Gamma\left(\frac{\beta}{1-\beta}\right)\left(\frac{\bar{A}^{H}}{\bar{A}^{L}} \frac{H}{L}\right)^{-\frac{1}{\theta}}\left(\bar{A}^{H} H\right)^{-\frac{1}{\theta(\sigma-1)}}
$$

where $\Gamma=\left(\frac{\sigma}{\sigma-1}\right)^{\frac{1}{\theta}}\left(\sigma F_{X}\right)^{\frac{1}{\sigma-1}}$. Compared to the case of perfect competition (see equation (12)), the elasticity (in absolute values) of the price $P_{X}$ to an increase in the supply of highly educated, $\bar{A}^{H} H$, is now higher $\left(\frac{\sigma}{\theta(\sigma-1)}\right.$ versus $\frac{1}{\theta}$ ). That is, the decrease in $P_{X}$ (and therefore in the overall price index) in response to an increase in the supply of highly educated is larger now. Combining the effect on wages and prices, we obtain that the real wage of highly educated workers does not decrease in this case by as much as the neoclassical supply effect would predict and that the real wage of less educated workers increases by more than before. This implies that the extra total real output (wages) generated by the increase in the supply of highly educated workers is higher than that generated in the benchmark case. Hence, there must be some external effect accruing to the workers. Equations (21) and (22) also show that keeping the supply of highly educated, $\bar{A}^{H} H$, constant, a change in the supply of less educated, $\bar{A}^{L} L$, only has the neoclassical (relative supply) effects on $\widehat{W}_{X}$ and $P_{X} \cdot{ }^{6}$ In short, the model presented in this section generates positive externalities from increases in the education of highly skilled (changes in the skill distribution above the threshold level $\bar{Z}$ ) and no external effects for improvements in the education of low-skilled (changes in the distribution below $\bar{Z}$ ).

\subsection{Adding Trade to the Model}

The most plausible, although analytically most intricate, case is one in which the two states are not only open in their access to technology but can also trade with each other. As state economies produce a combination of tradeable and non-tradeable goods and services we capture imperfect tradeability by introducing a trade cost. For simplicity we assume iceberg trade costs of $\tau$ for the differentiated good $X,{ }^{7}$ and no trade costs for the homogenous good $Y$. Except for the addition of trade costs, the model with trade mimics that in the previous section. Therefore we relegate the details to the Appendix and just present the equilibrium conditions with a balanced trade account between states.

As each state produces a number of different varieties of good $X$, the market clearing conditions for varieties of good $X$ produced in each state are given by

$$
\begin{aligned}
& \vartheta_{11} s\left(P_{X 1}\right) \bar{A}_{1}^{L} L_{1}+\vartheta_{12} s\left(P_{X 2}\right)\left(\bar{A}_{2}^{L} L_{2}+\widehat{W}_{X 2} \bar{A}_{2}^{H} H_{2}\right)=\left(1-\vartheta_{11} s\left(P_{X 1}\right)\right) \widehat{W}_{X 1} \bar{A}_{1}^{H} H_{1} \\
& \vartheta_{22} s\left(P_{X 2}\right) \bar{A}_{2}^{L} L_{2}+\vartheta_{21} s\left(P_{X 1}\right)\left(\bar{A}_{1}^{L} L_{1}+\widehat{W}_{X 1} \bar{A}_{1}^{H} H_{1}\right)=\left(1-\vartheta_{22} s\left(P_{X 2}\right)\right) \widehat{W}_{X 2} \bar{A}_{2}^{H} H_{2}
\end{aligned}
$$

\footnotetext{
${ }^{6}$ To be precise, a change in the skill distribution, below and above $\bar{Z}$, changes the equilibrium value of $\bar{Z}$ and hence indirectly the amount of effective skills of highly educated, $\bar{A}^{H} H$. However, for the changes in $\bar{A}^{L} L$ we consider in section 3.1, the indirect effect on $\bar{A}^{H} H$ through $\bar{Z}$ is negligible.

${ }^{7}$ For one unit of any variety of good $X$ to arrive $\tau>1$ units must be shipped.
} 
where the subscripts 1 and 2 refer to the state, $\vartheta_{i i}$ and $\vartheta_{j i}$ are the shares of the expenditure on good $X$ that consumers in state $i$ devote to local and imported varieties, respectively, and the other variables are defined as in the previous section. The similarity of (23) with the condition in (20) is apparent. The difference is that now only a share $\vartheta_{11} s\left(P_{X 1}\right)<s\left(P_{X 1}\right)$ of income of workers in state 1 is spent on varieties produced in that state, while the term $\vartheta_{12} s\left(P_{X 2}\right)\left(\bar{A}_{2}^{L} L_{2}+\widehat{W}_{X 2} \bar{A}_{2}^{H} H_{2}\right)$ represents the demand for varieties produced in state 1 coming from the other state (the term $\vartheta_{21} s\left(P_{X 1}\right)\left(\bar{A}_{1}^{L} L_{1}+\widehat{W}_{X 1} \bar{A}_{1}^{H} H_{1}\right)$ operates symmetrically for state 2). It is easy to show that for zero trade costs $(\tau=1)$ the equations in (23) add up to an expression identical to (20) relative to the aggregate of the two states (that we can call the U.S.) with the variables defined as $G_{U S}(Z)=G_{1}(Z)+G_{2}(Z), \bar{A}_{U S}^{L} L_{U S}=\bar{A}_{1}^{L} L_{1}+\bar{A}_{2}^{L} L_{2}$ and $\bar{A}_{U S}^{H} H_{U S}=\bar{A}_{1}^{H} H_{1}+\bar{A}_{2}^{H} H_{2}$. An increase in the effective supply of highly educated workers in state $i, \bar{A}_{i}^{H} H_{i}$, would then have a positive external effect on the U.S. real income. That is, the external effect would be perfectly diffused between the two states because free trade allows them to equally benefit from the increased variety of good X. However, as long as there are some trade costs $(\tau>1)$, we have a "home-bias" in the purchase of varieties of $X$ so that $\vartheta_{21}<\vartheta_{11}\left(\vartheta_{12}<\vartheta_{22}\right)$ and the external effect is larger (localized) within the state experiencing the increase in the supply of skilled workers. ${ }^{8}$ In the case of positive trade costs the complications in the algebra make it impossible to obtain clearcut expressions for $\widehat{W}_{X i}$ and $P_{X i}$ as a function of the relative skill supplies. Hence we rely on the simulations to obtain the relevant results. As we will show in section 3.1, the higher the trade costs, the more localized the externalities will be.

\section{$3 \quad$ Measuring the TFP Effects of Increased Schooling}

The source of schooling externalities in our model is clear. There are pecuniary externalities derived from the increased variety of the differentiated good produced in the high-tech sector. More precisely, since the technology of this sector is complementary to highly educated workers, a larger share of those workers (that is, an increase in $H$ in a given state) or higher average schooling of this group (an increase in $\bar{A}^{H}$ ) leads to an expansion of the modern sector and to a positive TFP effect. By contrast, an increase in the share (or schooling) of the less educated workers has only an impact on the production of good $Y$ with no TFP effects. While the mechanism is rather specific, the spirit of the model is very general. The existence of technologies that are highly productive and complementary to high-skilled workers implies that when this group expands those technologies become more prevalent and the sectors using them expand. If there are externalities (from increased varieties, learning spillovers or other sources) associated with those technologies/sectors then there will be a positive TFP effect.

Our purpose is to use the model to quantify the effect on total factor productivity (TFP) of different shifts

\footnotetext{
${ }^{8}$ Trade costs are key to identify the TFP effects of schooling in the empirical analysis. If the externality of an increase in highly skilled workers in a state was perfectly diffused between states we would not be able to empirically identify it using the cross-state variation.
} 
in the educational distribution of workers. Since workers are the only factor of production in our model, and employment is standardized to one, real per capita income is equal to the average real wage, $G D P=\bar{W} / P=$ $w=\int_{0}^{1} w(Z) \phi(Z) d Z$ where $w(Z)=W(Z) / P$ is the real wage for workers of skill $Z$ and $\phi(Z)$ is the density distribution function of workers over skills (so that $\int_{0}^{z} \phi(Z) d Z=G(z)$ ). Our measure of total factor productivity will be based on real wages. As is evident from equations (21) and (22), in the model with externalities an increase in the supply of highly educated has the typical neoclassical (or relative supply) effect on wages and prices, captured by the term $\left(\frac{\bar{A}^{H} H}{\bar{A}^{L} L}\right)^{-\frac{1}{\theta}}$, but it also has an additional positive external effect on relative wages and prices, captured by the terms $\left(\bar{A}^{H} H\right)^{\frac{\theta-1}{\theta(\sigma-1)}}$ and $\left(\bar{A}^{H} H\right)^{-\frac{1}{\theta(\sigma-1)}}$, respectively. In order to disentangle one effect from the other we adopt the method developed by Ciccone and Peri (2006): the "constant composition" approach. Based on the "dual approach" to growth accounting, the idea is to measure changes in (real) output by measuring the changes in (real) factor prices (in this case wages, as labor is the only factor of production). This method isolates the external or TFP effect of schooling as follows. First, by fixing the skill composition at its initial level, changes in output per worker due to increased skills are eliminated; second, by weighting wage changes by the initial skill composition the neoclassical (supply) effects on wages due to complementarities cancel out. The remaining changes in constant-composition wages are non-zero only in the presence of a change in total factor productivity (the external effect) ${ }^{9}$. Ciccone and Peri (2006) show that the percentage change in wages weighted by the initial factor shares in total income, or analogously, the percentage change in average wages at constant composition of skills, isolates the external effect of an aggregate schooling change. That is, the TFP impact of a discrete change in the skill distribution from $G_{0}(Z)$ to $G_{1}(Z)$ can be computed as follows

$$
\Delta \ln (T F P)=\frac{T F P_{t_{1}}-T F P_{t_{0}}}{T F P_{t_{0}}}=\frac{\int_{0}^{1}\left[W_{t_{1}}(Z) / P_{t_{1}}\right] \phi_{t_{0}}(Z) d Z-\int_{0}^{1}\left[W_{t_{0}}(Z) / P_{t_{0}}\right] \phi_{t_{0}}(Z) d Z}{\bar{W}_{t_{0}} / P_{t_{0}}}
$$

where the subscript $t_{0}$ refers to the initial values and the subscript $t_{1}$ refers to the values after the change. $W(Z) / P$ are real wages and $\phi(Z)$ is the density distribution function of skills defined above.

The formula is a first order approximation (as it omits second order terms) and in expression (24) it is written using the initial skill composition. If the second order terms are not too large the formula would also hold (approximately) using the final $\left(\phi_{t_{1}}\right)$ distribution of skills. The next section simulates the model and utilizes this method to calculate the effects of changes in schooling on TFP.

\footnotetext{
${ }^{9}$ We refer the reader to Ciccone and Peri (2006) for details on this procedure.
} 


\subsection{Parametrization and Simulated Effects on TFP}

We calibrate the model to U.S. data and then simulate the effects of changes in the educational distribution that took place in the U.S. during the period 1960 to 2000 on TFP. ${ }^{10}$ We use a value of $\theta$ (the elasticity of substitution between $X$ and $Y$ ) equal to 1.5, which is the consensus estimate for the elasticity of substitution between more and less educated workers (Katz and Murphy, 1992, and Ciccone and Peri, 2005). The value of $\sigma$ is chosen to be equal to 2, consistent with the average estimate of the elasticity of substitution between "differentiated tradable goods" (Broda and Weinstein, 2006). Based on data from the Consumer Expenditure Survey (Bureau of Labor Statistics, 2005), the parameter $\beta$ is chosen to be 0.65 corresponding to the share spent on advanced goods and services (including all consumption goods except for food, apparel and personal services). ${ }^{11}$ Finally, the technological parameters $g_{X}$ and $g_{Y}$, which equal the returns to education in the two sectors, and $F_{X}$, the fixed set-up costs for the advanced technology, are calibrated to match the average wage schedule for the U.S. over the period considered. As illustrated in Panel 1, the wage schedules for U.S. workers exhibit a change in slope between 11 and 12 years of schooling (high school graduation) which became stronger after 1970. Accordingly, we can calibrate $g_{Y}$ and $g_{X}$ to match the slope of the wage schedule above and below 12 years of schooling. The slope below 12 years $\left(g_{Y}\right)$ has declined slightly over the decades and the average slope above 12 years of schooling $\left(g_{X}\right)$ has increased. Their average values for the period 1960-2000 was roughly equal to their value in 1980. Keeping in mind that one year of schooling corresponds to an increase in $Z$ of 0.05 , the returns to years of schooling for 1980 correspond to $g_{Y}=0.4$ and $g_{X}=1.6$, respectively.

The schooling groups and the distribution of U.S. workers over these groups for the period 1960 to 2000 are reported in Table 1. One can see that for the period considered the two groups of workers with less than 12 years of schooling shrunk significantly while the percentage of college graduates in total employment more than doubled. Using the overall U.S. schooling distribution of the labor force in 1980 as the starting point and the parameters described above we conduct the following two experiments. First, we shift $6 \%$ of the labor force from the lowest educational group ( 0 to 8 years of schooling) to the next group ( 8 to 11 years of schooling). This shift matches the average reduction per decade in the lowest educational group (from $28 \%$ of the employed in 1960 to $4 \%$ in 2000) and to a large extent mirrors the effect of the compulsory schooling laws. This shift implies an average increase of 0.36 years of schooling per worker. In the second experiment we consider an equivalent increase in average schooling obtained instead by augmenting the education level in the upper part of the schooling distribution. To that end we increase the share of college graduates by moving people out of the college dropouts group. For this shift to increase average schooling by 0.36 years, the share of college graduates in the overall workforce needs to be increased by 10 percentage points.

\footnotetext{
${ }^{10}$ The details of the model parametrization and calibration are given in Appendix 2.

${ }^{11}$ Sensitivity tests, not reported here due to space limitations, were performed for $\beta$ in the interval 0.55 to 0.7 . The relevant estimates of the externalities are quite stable to changes in this parameter.
} 
Table 2 shows the simulated effects on TFP (externalities) of these two shifts for the various versions of the model presented above. The first row reports the external effect of an increase in average schooling due to an increase in high school attendance (first experiment) whereas the second row shows the external effect of increased college education (second experiment). The third row shows the ratio of the two effects. The effects are standardized so that they can be read as the percentage TFP increase for an increase in one year of schooling per worker achieved with either shift. Column 1 presents the results obtained using the model with perfect competition presented in section 2.2. As explained above, an increase in the education of either group has the standard neoclassical effect on the effective relative wages but no external effect; in this scenario the increased output produced by an increase in schooling of some individuals is all privately appropriated. By contrast, using the model with monopolistic competition and product variety described in section 2.3 we find evidence of significant localized TFP effects, especially in the case of increased college education. In particular, considering the case with no trade (column 2), a one-year increase in average high school attendance barely has an effect on the state's TFP (1\%) while a comparable increase in college education has an external effect of 8.9\%. This localized TFP effect is reduced when $X$ is considered tradeable across states as the external effect then spills over to other states. In the empirical cross-state analysis we are only able to identify the increases in a state's TFP above and beyond the average increases in the national TFP. Therefore in the simulations of the model with trade (column 3 and beyond) we report the "differential" impact on TFP: the difference is between a state in which the supply of skills increases and the other state where the supply remains unchanged. We consider a value of trade costs equal to 2 (column 4 and beyond) as most plausible. Although costs equal to $100 \%$ of the traded value $(\tau=2)$ are high for traded goods, many of the advanced services included in $X$ (e.g. education, health care, real estate services) are non-tradeable and thus one can think of their trade costs as being much higher than $100 \%$. In order to approximate the combination of tradeable and non-tradeable differentiated goods and services we choose a relatively large average for the trade cost $\tau$. Under this assumption, the localized externalities due to an increase in the share of college graduates (column 4) is more than $5 \%$ per one extra year of schooling while the externalities due to high school education are only half of a percentage point. With trade costs equal to $50 \%$ (column 3) we still obtain localized externalities of $3.25 \%$ for one extra year of college per worker and only $0.27 \%$ from one extra year of high school per worker.

Column 5 shows the results from the same two experiments and the same model as in column 4 , but using values for the returns to skills in the modern sector that match the higher returns observed in the later decades, 1990 and 2000. In particular, we use a value of $g_{X}=2.7$ which implies returns to an extra year of schooling in the high-tech sector of around 13.5-14\% (versus the benchmark value of $8 \%$ ). Accounting for higher returns to skills for the highly educated is important because these returns might interact with and strengthen the externality. Indeed, the productivity effect of increasing high school attendance is now around $1 \%$ while the 
change in TFP when college graduation is increased increases to 7.9\%. Finally, column 6 calculates the localized externalities when the state experiencing the increase in schooling initially has a larger share of the high-tech sector because of a more educated labor force (calibrated to be one standard deviation above the U.S. average schooling in 1980). In particular we check whether an initial specialization in the high-tech sector, combined with higher returns to high skills, affect the size of the external TFP effects. The effects are, however, very similar to those in column 5.

\subsection{From the Model to the Data}

Our model captures the inter-relations between education, technology and productivity. It shows that if the technologies of different sectors have different degrees of complementarities with education, economies sharing the same technological options and trading with each other, but with different schooling distributions such as the U.S. states, will have different patterns of sectorial specialization. If there are positive external effects associated with the high-tech sector such as the production of differentiated varieties of goods or learning spillovers, as well as imperfect tradeability of goods and services, then localized schooling externalities arise. Moreover, as it is more educated workers (with more than 12 years of schooling) who adopt the skill-complementary technology, only increases in college education generate the positive external effect while increases in high school attendance increase only the private returns to workers. Indeed, the simulations show that for plausible elasticities of substitution between varieties of the differentiated good the externalities from college education are much larger than those from high school. However, there are other potential factors that might affect total factor productivity and that need to be taken into account in the empirical estimation. One of them is nation-wide exogenous skill-biased technological change. If all states had the same initial sectorial composition, then skill-biased technological change would affect TFP in all states in the same way. However, if the states differ in their initial sectorial composition skill biased technological progress, even if common to all states, will have a differential impact on TFP across states. Consider, for instance, the following scenario. Suppose that a state with larger initial shares of the high tech sector experiences an increase in its supply of high skills at the same time as there is nation-wide exogenous skill-biased technological change. The effect on TFP of skillbiased technological change could be confounded with schooling externalities. Using the model we can easily disentangle the two effects, ${ }^{12}$ though this becomes more challenging in the empirical estimation. We try to isolate the schooling externalities from other TFP effects in two ways. First, we identify supply-driven shifts in the educational attainments across states and use them as instruments for the changes in schooling. We build

\footnotetext{
${ }^{12}$ For instance, if we want to compute the effect of common skill-biased technological change in isolation, we only need to increase the value of the technological parameter $g_{X}$ relative to $g_{Y}$ while keeping the schooling distributions across states unchanged. We simulated such effect by taking 2 states with different schooling distribution as in column 6 on Table 2, and then considered an increase in $g_{X}$ from 1.6 to 2.7 common to both states. The state with the higher share of highly educated experienced a differential increase in TFP of $13 \%$.
} 
and improve on previously used instruments, and we test their validity and robustness. Second, to further ensure that the instruments isolate the supply-driven shocks (especially for the college attainment instruments) and not persistent demand-driven (sector-composition) shocks, we include controls accounting for the initial sector composition across states and the induced sector-specific productivity growth to absorb the demand-driven effect on TFP and on human capital changes.

\section{Empirical Evidence from U.S. States, 1960-2000}

\subsection{Empirical Methodology and Data}

The data used in the empirical analysis are mostly from the Integrated Public Use Microdata Samples (IPUMS herein) of the US Censuses 1960-2000 collected, homogenized and made available by Ruggles et al. (2005). We select only individuals between 16 and 65 years of age who worked at least one week in the previous year, earned some wage income and did not live in group quarters. The construction of the TFP changes for each U.S. state over the four decades 1960-2000 follows the procedure developed in Ciccone and Peri (2006), and is simply the empirical counterpart to expression (24) of the model and simulations. We compute the constant composition average wage in two stages. In the first stage we regress the logarithm of the real weekly wage $\mathrm{e}^{13}$ for individual $i$ in state $s$ and census year $t, \ln w_{i s t}$, on a set of individual characteristics, $X_{i t}$, (including gender, race, US-born, marital status) and a set of dummies, $\ln \omega(H, E)_{s t}$, that saturate the schooling $(H)$ by experience $(E)$ space in 32 cells combining four schooling groups and eight experience groups. ${ }^{14}$ That is, we run the following regression:

$$
\ln w_{i s t}=\ln \omega(H, E)_{s t}+\lambda_{t} X_{i t}+\varepsilon_{i s t}
$$

The regression, ran separately for each census year $t$ and state $s$, is estimated by weighted least squares using the individual's weights provided by the Census. The set of dummy variables $X_{i t}$ is chosen so that the "cleaned" estimated wage, $\ln \widehat{\omega}(H, E)_{s t}$, for each education $(H)$ - experience $(E)$ group corresponds to white, US-born, married male workers. In the second stage we use the cleaned wages by state and year obtained from (25) and the employment distribution by schooling-experience in each state-year to construct the constant-composition average wage for each state and decade. If we denote the employment shares of workers in each of the educationexperience groups in state $s$ for census year $t$ by $\phi_{s t}(H, E), H \in\left\{H_{1}, \ldots H_{4}\right\}, E \in\left\{E_{1}, \ldots E_{8}\right\}$, the intercensus

\footnotetext{
${ }^{13}$ The real wage is calculated by deflating nominal wages by the CPI; it is expressed in 2000 US $\$$. Yearly wages are divided by the number of weeks worked in order to obtain weekly wages. As the variable "weeks worked" is categorical in the IPUMS for years 1960 to 1980 , we use the median point of the interval for those years. As an alternative we also use hourly wage.

${ }^{14}$ The educational groups are the four traditionally used in the labor literature: $H_{1}=[0,12)$ for High School Dropouts, $H_{2}=$ $[12,13)$ for High School Graduates, $H_{3}=[13,16)$ for College Dropouts, and $H_{4} \geq 16$ for College Graduates. The experience groups are eight groups of 5 -year intervals spanning between 0 and 40 years.
} 
change in the constant-composition average wage is given by:

$$
\Delta \ln (T F P)_{s t}=\Delta \ln w_{s t}^{c c}=\ln \sum_{S, E}\left(\phi_{s, t}(H, E) \widehat{\omega}(H, E)_{s, t+10}\right)-\ln \sum_{S, E}\left(\phi_{s, t}(H, E) \widehat{\omega}(H, E)_{s, t}\right)
$$

where the superscript $c c$ denotes "constant composition" and we have expressed the percentage changes as logarithmic changes. Using this measure in the next section we will analyze the relation between the change in TFP and the changes in schooling across U.S. states.

\subsection{High School Education, College Education and TFP}

We start by showing correlations between changes in schooling attainments and changes in TFP across US states. As illustrated in equations (21) and (22), the relative wage of highly skilled and less skilled workers as well as the external effects of skills on TFP depends upon the supply of effective skills of these groups, $\left(\bar{A}^{H} H\right)$ and $\left(\bar{A}^{L} L\right)$. These, in turn, are monotonic functions of the aggregate skill level of each group that we define as:

$$
\bar{Z}^{L}=\int_{0}^{\bar{Z}} Z d G(Z) \quad \bar{Z}^{H}=\int \frac{1}{Z} Z d G(Z)
$$

As total employment is standardized to $1, \bar{Z}^{L}$ and $\bar{Z}^{H}$ measure the years of schooling of less educated relative to total employment and the years of schooling of highly educated relative to total employment, respectively. We construct an empirical counterpart to those measures as follows. We compute the years of schooling of workers with at most a high school diploma and divide them by the total number of workers. We call this summary measure "years of high school per worker" and denote it with $\overline{s c h o o l}^{H S}$. This is our proxy for $\bar{Z}^{L}$. Similarly, we compute the "years of college per worker" (denoted as $\overline{s c h o o l}^{C O L L}$ ) as the years of schooling of workers with college education divided by the total number of workers. We use this variable as a proxy for the average skills of more educated workers $\left(\bar{Z}^{H}\right)^{15}$. The advantage of using $\overline{\text { school }}^{H S}$ and $\overline{\text { school }}^{\text {COLL }}$ across states and census years is that they are directly comparable because a one-year increase in either of them represents an increase in overall average schooling of one year. Hence the estimated effects of these variables on TFP are comparable with each other, are comparable to the simulated effects of Table 2 and can also be compared with the external effect of one extra year of schooling obtained in previous studies (e.g. Acemoglu and Angrist, 2001, or Ciccone and Peri, 2006).

Figure 2 reports the percentage change in TFP, measured as $\Delta \ln w_{s t}^{c c}$, against the change in years of high school per worker, $\Delta \overline{s c h o o l}_{s t}^{H S}$, for 50 U.S. states plus D.C. over two decades (1980-90 and 1990-2000) pooled

\footnotetext{
${ }^{15}$ The terms "years of high school per worker" and "years of college per worker" may seem inaccurate. After all, the group of workers with at most a high school degree also attended years of elementary school and the group with college education also attended elementary and high school. However, as we identify the externalities on inter-census changes, the differences in the two variables between censuses is indeed moslty due to years of high school attendance for the first group and years of college attendance for the second group.
} 
together. Figure 3 reports, for the same sample, the change in TFP against the change in years of college per worker, $\Delta \overline{s c h o o l}_{s t}^{C O L L}$. In both graphs the variables are in deviations from the decade-specific average. While there is no correlation at all between TFP changes and increases in years of high school per worker across states, we observe a strong and significant correlation between TFP changes and changes in years of college per worker. The estimated slope in Figure 3 implies a 15\% increase in TFP for an increase of one year of college education per worker. Although the scatter-plots do not establish any causal relationship and are only drawn from the most recent decades, 1980-2000, they already convey the essence of our empirical findings: only increases in college education are associated with sizeable and significant external TFP effects ${ }^{16}$.

Table 3 reports the OLS coefficients when we simultaneously include $\Delta \overline{s c h o o l}_{s t}^{C O L L}$ and $\Delta \overline{s c h o o l}_{s t}^{H S}$ as regressors of $\Delta \ln w_{s t}^{c c}$. The table shows that the basic correlations identified in Figures 2 and 3 are robust to the simultaneous inclusion of both regressors and to several changes in the specification. In particular, the basic specification (1) in Table 3 reports the estimates from the following regression:

$$
\Delta \ln w_{s t}^{c c}=\alpha_{t}+\beta_{1} \Delta \overline{s c h o o l}_{s t}^{H S}+\beta_{2} \Delta \overline{s c h o o l}_{s t}^{C O L L}+\varepsilon_{s t}
$$

where $\alpha_{t}$ are census year fixed effects, each variable measures the change in the 50 U.S. states plus D.C. over each decade of the 1960-2000 period and $\varepsilon_{s t}$ denotes uncorrelated zero mean errors. The method of estimation used is least squares with each observation weighted by the employment in the cell and standard errors clustered at the state level. The estimates reported in column 1 of Table 3 show that an increase in one year of college per worker is associated with an almost $7 \%$ increase in the state TFP, while an increase of one year of high school per worker is associated with an insignificant $1.3 \%$ increase in TFP. Similar results (with a slightly larger college externality) are obtained when we control for three regional dummies (specification 2), whereas when we restrict the sample to the most recent 3 or 2 decades the strength of the positive correlation between TFP changes and college education increases (specification 3 and 4). In particular, specification 4 shows a $15 \%$ externality of one extra year of college per worker for the 1980-2000 period, while the years of high school per worker still have a statistically insignificant coefficient of 0.01. Finally, omitting California, the largest recipient of immigrants (specification 5) and restricting the wage calculations to white US-born males (specification 6) barely changes the estimates. These correlations are qualitatively and quantitatively consistent with the model presented and simulated above. As in the simulations, the external effects of high school education are never above 1-2\% of TFP. With regard to college education, the estimated external effects are between $7 \%$ and $10 \%$ for the whole sample and even higher (up to 15\%) for the recent decades, consistent with the simulations (with transport

\footnotetext{
${ }^{16}$ The qualitative features of Figures 2 and 3 do not depend on the choice of decades. For any decade (from 1960 to 1990 ) considered one by one or in groups, the correlation between changes in TFP and $\Delta \overline{s c h o o l}_{s t}^{H S}$ is never significant and occasionally negative (between -0.03 and 0.025), while the correlation between TFP and $\Delta \overline{s c h o o l}_{s t}^{C O L L}$ is always positive and significant (between 0.08 and 0.16$)$.
} 
costs between 2 and $\infty$ ) which showed localized externalities between $5 \%$ and $9 \%$.

\subsection{Instrumental Variables: Discussion and First Stage}

The obvious drawbacks to the OLS estimates presented above are the endogeneity problem and omitted variable bias. Rather than being the cause of higher TFP, highly educated workers might be attracted to states with highly productive sectors. Alternatively, the selection of highly educated workers to a state may be due to other (unobservable) characteristics of workers, resulting in a spurious correlation of TFP and schooling. In order to address these issues we adopt an instrumental variable strategy that uses three sets of state-specific determinants of schooling attainments produced by supply rather than demand factors. Two of these instruments, based on compulsory schooling laws and the location of Land Grant colleges, have been previously used in the immigration and externalities literature as shifters of the supply of workers across US locations. As the power of the Land Grant colleges instrument across states is rather weak, we also introduce geographical preferences of highly educated immigrants as an exogenous shifter of the supply of college educated. In particular we use the uneven distribution in 1960 of immigrants of some nationalities and the high immigration rates of highly skilled from those nations to construct a push-driven change in highly skilled immigrants across states. We discuss the construction and characteristics of each instrument separately in the remainder of this section.

\subsubsection{Mandatory Schooling Laws: Child Labor and Compulsory Attendance}

Our first set of instruments are the compulsory attendance (CA) and child labor (CL) laws first collected and used in Acemoglu and Angrist (2001) and in several other papers thereafter (Milligan, Moretti and Oreopoulos, 2004, Moretti and Lochner, 2004, Oreopoulos, Page and Stevens, 2006, Ciccone and Peri, 2005). These laws, in place between 1920 and 1970, affected the schooling level of several cohorts of Americans. They were introduced at different times across states and they also implied different requirements in terms of the years of schooling needed before one could access the labor market. Hence, using these data we can identify the minimum years of schooling required by the state where an individual resided at age 14 and attach that minimum requirement to each individual. As the $\mathrm{CA}$ laws required between 8 and 11 years of schooling in most cases, we calculate the share of workers in each state for which the associated CA laws mandated less than 8 years $(\mathrm{CA}<8)$ and those for which they mandated more than 11 years $(C A>11)$. We expect the first share to be associated with smaller values of the variable "years of high school per worker", and the second with higher values of that variable. We also use CL laws imposing between 6 and 9 years of schooling to construct the dummies $\mathrm{CL}<6$ and $\mathrm{CL}>9$ and corresponding measures of the share of people in each state associated with the first dummy (for which we expect a negative impact on $\overline{s c h o o l}_{s t}^{H S}$ ) and the share of workers associated with the second dummy (for which

we expect a positive effect on $\overline{s c h o o l}_{s t}^{H S}$ ). These four variables, presumably uncorrelated with productivity or 
the personal ability of workers across states, are indeed correlated with the schooling levels of individuals, as those laws significantly increased the rate of attendance for the 9th, 10th and 11th grades as well as high school graduation rates of the states in which they were introduced (relative to those in which they were not). Table 4 shows the explanatory power of these four variables in predicting changes in years of high school per worker (columns 1 and 2) as well as changes in the share of people without a high school degree (columns 3 and 4 ). The estimates are based on decade differences in US states plus DC and include decade fixed effects. Two remarks are in order. First, notice that each variable has the expected effect on years of high school per worker (positive for $\mathrm{CA}>11$ and $\mathrm{CL}>9$ and negative for $\mathrm{CA}<8$ and $\mathrm{CL}<6$ ) as well as on the share of high school dropouts (negative for $\mathrm{CA}>11$ and $\mathrm{CL}>9$ and positive for $\mathrm{CA}<8$ and $\mathrm{CL}<6$ ) in all specifications 1 through 4 . Second, most of the coefficients in specifications 1 through 4 are significant at the $5 \%$ level. The joint F-test of significance for the overall set of instruments always rejects the hypothesis that they are jointly insignificant at the $1 \%$ confidence level. The F-statistic drops quite a bit when we add region-specific effects (specifications 2 and 4), although it is still higher than 5 and, as mentioned, still statistically significant at the $1 \%$ level. As a check we use the same schooling law shares to predict the share of college graduates across states (columns 5 and 6). We obtain no significant coefficients. Furthermore, in this case the F-statistic for the joint significance of schooling and labor laws is always lower than 3 , and one can never reject the null hypothesis of zero significance at the $1 \%$ confidence level. As shown by Acemoglu and Angrist (2001), these schooling laws did not generically increase average schooling; they did so by increasing high school attendance rates and high-school graduation rates. In other words, they shifted the schooling distribution in its "low" range, leaving the high-end range unchanged.

\subsubsection{Land Grant Colleges}

An instrument affecting the margin of college attendance and graduation across states is the presence of a college close to where a large share of the college-age population resides. Card (1993) found that the presence of a fouryear college in the same labor market positively affected the probability that an individual attended college and graduated from it. Currie and Moretti (2003) used the same idea of college proximity to instrument mothers' education in analyzing the latter's effects on children's health. Proximity to college reduces the (material and psychological) costs of attending college inducing some individuals, who would not have otherwise continued after high school, to get further education. Moretti (2004) uses the presence of a Land Grant college in a metropolitan area as a predictor of its share of college educated. Land Grant colleges were established in the late 1800's as a result of a movement to provide accessible higher education to people in each U.S. state. As a consequence their initial location is not correlated with returns to education in the late 1900's. Moreover, they are evenly distributed across the U.S., and they became well established, large institutions over time. Individuals living close to them are likely to have lower costs and thus a higher probability to attend them than 
others living farther away. As we intend to use proximity to college as an instrument for the share of college educated in the state, we need to look at the coincidence of Land Grant college location with the location of the population of college age. For each state we calculate the population between the ages 14 and 21 living in counties within 100 Kilometers (60 miles) from a Land Grant college in every census year (between 1970 and 1990) ${ }^{17}$. These data were obtained from the County and City Data Book, U.S. Bureau of Census $(2000)^{18}$. We then use the student-age population in proximity of a land-grant college as a percentage of the working age population in each state as a predictor of the change in the share of college educated in the following decade. As the push towards increased college attendance was different across decades we interacted those shares with decade dummies. Table 5 shows the power of these instruments in predicting the increase in the share of college educated workers during each of the three decades considered. There is a positive and significant correlation between the instruments and the increase in the college share in each decade, and the correlation is stronger for the nineties than for the eighties and seventies. For a $10 \%$ increase in the share of young residents living within 100 kilometers of a land grant college in the nineties, the share of college graduates in the state increased by almost 3 percentage points (column 1). Similarly that state experienced 0.46 more years of college education per worker (column 2). The joint F-test of the instruments is above 6 showing that overall there is a significant correlation although not too strong. The difference with Moretti (2004) who also uses Land Grant College as an instrument is that we use this variable to predict college education at the state level, rather than at the city level. At the state level the effect of Land Grant colleges (one per state) is diluted and our IV is not a very strong predictor of college education. We check whether the instrument shifts education also at the high school level (column 3). Such effect is positive and significant in the 1970's and 1980's but it is not significant (and negative) in the 1990's. While the correlation with high school education could still be an effect of the lower cost of college education, pushing more people to complete high school, it may also signal some unobserved features of states (e.g. labor demand, level of urbanization, sector composition) correlated with schooling improvements. Because of the limited power of this instrument and its limited ability to isolate changes in college education at the state level we develop and use an additional instrument.

\subsubsection{Imputed College Educated Immigrants}

Previous studies (Card, 2001, Lewis, 2004, Ottaviano and Peri, 2005 and Cortes 2006 among others) have used the uneven location of less educated Mexican and Latino immigrants in the 1960's, and the tendency of new immigrants to locate in the same state as previous immigrants, to construct changes in the supply of less educated workers. Distributing the total net inflow of less educated Mexicans in each decade to states in relation to their initial distribution, the cited studies construct a supply-driven imputed change of less educated

\footnotetext{
${ }^{17}$ We also utilized the number of potential students within 200 and $300 \mathrm{~km}$ from a land grant college with similar results.

${ }^{18}$ We are grateful to Jordan Rappaport for sharing these data with us.
} 
immigrants. By construction those imputed flows are only based on the initial distribution of foreign-born by nationality across states and on their total inflow into the US by nationality. As long as the initial distribution of immigrants across states is not correlated with the subsequent technological and productivity changes across states the constructed instrument isolates supply shifts. We adopt a similar strategy to construct imputed inflows of highly educated immigrants by state. Immigrants from non-Hispanic countries (especially India, China and Europe) are generally over-represented among college graduates while they are under-represented among highschool graduates and college dropouts. Hence, we construct an "imputed" inflow of college educated immigrants as follows. Using 1960 as the reference year, we compute the number of foreign-born workers residing in each U.S. state and born in each of 57 different foreign countries. We attribute to each national group in each state in 1960 the skill-composition of that group nationwide. While the initial share of highly educated workers in a state is likely to be correlated with its sector composition and therefore with its subsequent productivity changes, our instrument is based only on the initial distribution of immigrants by nationality and not by education. This way we take care of possible selection bias of certain educational groups to choose certain states. To the 1960 imputed number of college educated by country of origin and by state we apply the inter-decennial national growth rates of the college graduate population from each of those 57 nationalities. Using these values, that are by construction orthogonal to the state-specific productivity shocks, we then compute the imputed share of foreign-born graduates in total employment for each census year. This methodology exploits the fact that certain countries (such as India and China) sent many of their college graduates to the U.S. during the period considered. Further, if there is a higher probability that the new immigrants landed and stayed where previous immigrants from the same country (of any education levels) already were (for instance, due to networking, taste or informational reasons), then the imputed inflows of college educated will be correlated to the actual inflow of foreign-born college educated and, as a result, to the total supply of college educated workers in the state.

To emphasize the validity of our assumptions, notice that in the year 2000 in the U.S. as a whole foreignborn represented $8 \%$ of the college dropout group but $12 \%$ of the college graduate group. In some states (such as California) foreign-born constituted more than $25 \%$ of college educated employment. At the same time, the group of college educated from countries such as India, China and the European Union grew much faster than the group of U.S. born college graduates. During the period 1960-2000, the number of college educated from India, China and the European Union increased by 200 fold, 50 fold and 8 fold, respectively, while the number of college educated Americans rose by only 5 fold. These increases are a combination of the increased share of college graduates among immigrants of those countries and the increase in overall immigration from those countries (especially for China and India). In the year 2000, college educated from China, India and the European Union accounted for 6\% of all college graduates in the U.S., while in 1960 they accounted for $0 \%$. Hence, if immigrants tend to locate where their co-nationals already live, states with large initial shares of 
immigrants from those nationalities would have experienced a large supply shock of college educated. Table 6 shows the predictive power of the constructed share of college educated immigrants on years of college per worker (specifications 1 and 2), on the share of college educated (specifications 3 and 4) and on years of high school per worker (specifications 5 and 6) pooling decades and controlling for decade fixed effects. The constructed share has strong predictive power (very significant t-statistics and F-test) for the years of college per worker and for the share of college educated in the state, while it has no power at all for the years of high school per worker. The constructed instrument only shifts the schooling distribution at the high end of the schooling range. This implies that identification across states does not come simply from differences between high immigration and low immigration states but from specific nationalities that are associated with high levels of immigrant education and have a specific geographic distribution across states.

The tendency of highly educated workers to co-locate with previous immigrants from the same country should be smaller, however, than for less educated. Indeed, highly educated are more mobile than less educated workers and often move to specific jobs rather than generically joining the community of previous immigrants. Hence, we would expect such imputed share to have less power to explain the actual share of college graduates than the imputed share of less educated. We present some evidence of this in Figures 4 and 5 and Table 7. Figures 4 and 5 show the correlation between the imputed and the actual shares of foreign-born high school dropouts and college graduates, respectively, across states. Although significant, the imputed shares of highly educated foreign-born explain much less of the variation in the actual shares of highly educated foreign-born across states (Figure 5) than the equivalent imputed measure for high school dropouts (Figure 4). The R-squared of the regression in Figure 4 is 0.42 , while the R-squared in Figure 5 is 0.26 . In other words, factors other than the location of previous immigrants (such as technological growth or sector composition) affected the location of highly educated by much more than the less educated. Confirming this further, Table 7 shows a lower correlation between the imputed share of college educated immigrants and the total share of college educated than between the imputed share of high school dropout immigrants and the total share of high school dropouts across states. Yet, imputed college-educated immigrants still have significant explanatory power and their variation across states is quite large relative to the actual variation of college shares (see the ratio of standard deviations in Table 7). Tastes, imperfect information and network effects are factors that can potentially influence the location of immigrants, and even if they are likely to be less relevant for highly educated than for less educated, they still have enough predictive power to construct a workable instrument. Moreover, in our empirical analysis we use the imputed college-educated immigrants jointly with the Land Grant instrument in order to increase the power of the IV estimation and we assess their exogeneity using the test of overidentifying restrictions. 


\subsection{Estimates}

Table 8 reports the 2SLS estimates of externalities from years of high school per worker (first row) and years of college per worker (second row). The basic specification estimated is (27) using decade changes for the US states and D.C. over the period $1970-2000^{19}$ and the method of estimation is 2SLS using the CA-CL laws, the Land Grant College proximity and the imputed college-educated immigrants as instruments. We include all of them in order to increase the power of the instruments. We also test for their exogeneity using the test of overidentifying restrictions as described in Woolridge (2002). The test statistic, reported in the third row of Table 8, is distributed as a Chi-squared with 6 degrees of freedom under the null hypothesis (that no instrument enters the estimating equation directly). ${ }^{20}$ The first column of Table 8 reports the 2SLS estimates of the basic regression (the counterpart to the OLS estimates in the first column of Table 3). The TFP effects from one extra year of high school per worker is negative $1 \%$, though insignificantly different from 0 , while the TFP effects of one extra year of college per worker is $6 \%$, significantly different from 0 . Relative to the OLS estimates, the IV estimates are smaller by 1-2 percentage points. This supports the notion that demand-driven TFP growth might have biased the OLS estimates upwards. Moreover, the 2SLS estimates are even closer than the OLS to the simulated effects from the model with costly trade (column 4 in Table 2). The test of overidentifying restrictions cannot reject the null hypothesis of exogenous instruments at a significant confidence level. Column 2 reports the estimated externalities when the percentage TFP increase, $\Delta \ln w_{s t}^{c c}$, is measured as described in expression (26) but fixing the skill composition in each state equal to its value at the end (rather than at the beginning) of the decade. The estimates and the test statistics are almost unchanged. Specification 3 shows the estimated effects when the dependent and explanatory variables are constructed including only male workers, while specification 4 omits California, a potential outlier in terms of the presence of foreign-born. The estimated high school externalities remain between plus and minus $1 \%$, never significantly different from 0 , while the estimated college externalities are between 5 and $6 \%$, always significantly positive at the $5 \%$ significance level. Finally specifications 5 and 6 restrict the regression to the most recent decades 1970-1990 and 1980-2000. Consistent with the OLS estimates and with the model simulations, the TFP impact of one extra year of college is larger, although more imprecisely estimated, when we consider only the more recent decades. The TFP effect of college education in the 1980's and 1990's is estimated to be $12 \%$ while the effect of high school education is still insignificantly different from 0. Despite the large value, once we account for its standard deviation (4\%), the estimate is not significantly different from the simulated value of $8 \%$ from column 5 of Table 2 . We should also keep in mind that restricting the analysis to the last two decades significantly reduces the power of the instruments and hence increases the standard error and the potential weak-instrument bias.

\footnotetext{
${ }^{19} \mathrm{We}$ omit in the 2SLS estimation the 1960's as data on college age population by county in 1960 (used to construct the Land Grant instrment) is not available from the City and County Databook.

${ }^{20}$ The degrees of freedom are determined by the number of the instruments, eight in this case (4 CA-CL shares, 3 Land-Grand College variables and one imputed immigrants' college-share) minus the number of the endogenous variables (2).
} 
Previous literature has not simultaneously estimated the external effects of years of high school and years of college. However, the available IV estimates of average schooling externalities (from Acemoglu and Angrist, 2001, and Ciccone and Peri, 2006) using CA-CL as exogenous shifters of schooling are mostly within the range obtained in Table 8 for high school externalities $(-1$ to $+1 \%)$ and statistically insignificant. On the other hand, the existing estimates of externalities from college-educated (Moretti, 2004) are around 1\% for each $1 \%$ increase in the share of college graduates. Assuming that the increase in college graduates corresponds to a decrease in high school graduates of the same amount, Moretti's estimates imply an external effect of $25 \%$ for each extra year of college per worker. His estimates are based on data from the eighties and nineties. Our estimates for that period are around $12 \%$, large and significant, and about half of the effect estimated by Moretti ${ }^{21}$. Finally let us notice that none of the IV estimates of the externalities from schooling is negative and significant. If the only role of education were to signal unobservable productivity of workers, exogenous changes of education across states, such as those driven by schooling laws or Land Grant Colleges, would produce negative externalities. By reducing the cost of education they would induce lower quality workers to get higher education so that a certain level of schooling per worker would be associated with lower productivity. We find no evidence of such negative externalities.

\subsection{Sector-Driven College Education and Sector-Specific Productivity Growth}

While the previous IV estimation produces sensible results, reduces the potential OLS bias in the right direction and the instruments prove to be reasonably powerful and pass the exogeneity test, one can still worry about demand shocks that are correlated with the initial distribution of high skills and that affect TFP while attracting college educated at the same time. In particular, the initial sector composition of a state, interacted with sector-specific productivity growth and human capital intensity may be the underlying cause of the estimated correlation between college education and TFP. In this section we address this problem explicitly by controlling for the effect of the initial sector-composition on the demand for highly educated workers and on the productivity growth of the state. In the first set of regressions, reported in Table 9, we construct an "imputed" increase in the share of college educated workers across states driven by their initial sector-composition. We take the composition of employment in each state in 1960 over 41 different sectors (the classification is close to a 2-digit classification, based on the variable IND1950 in the census and follows the one used in Hanson and Slaughter, 2002). We then apply for each sector in each state the growth rate in college graduate employment experienced by that sector nationwide in each decade between 1960 and 2000. Adding across industries for each state and year and dividing by total workers yields a "sector-driven" imputed share of college graduates in the labor force. This measure proxies for the demand-driven increase in college-educated in each state and is included as

\footnotetext{
${ }^{21}$ Moretti (2004) is aware of the very large size of his estimated externalities (see his discussion on page 195). Differences with our estimates may arise from his choice of cities, rather than states, and differences in the set of instruments used.
} 
a further control in the regressions in Table 9. This variable is significantly correlated with the actual change in years of college per worker (correlation coefficient of 0.73) indicating that demand factors are important determinants of changes in college educated workers. It is also mildly correlated (correlation coefficient 0.33 ) with the imputed immigrant share of college graduates used as IV. Consequently, including it as a control allows us to be more confident that the OLS and the IV coefficients on the variable $\Delta \overline{s c h o o l}_{s t}^{C O L L}$ isolate a supplydriven externality rather than a demand (sector-)driven correlation. Table 9 reports the OLS estimates of the externalities (columns 1 to 3 ) as well as the IV estimates (columns 4 to 6 ) including the sector-based imputed share of college graduates as a control. Relative to the basic ones in Table 3, the OLS estimates show a smaller TFP effect of college education, closer to $6 \%$, and no externality from high school years of schooling. The IV estimates of college externalities are somewhat larger (between 9 and 11\%) and less precise, still compatible with the simulated values of Table 2 . We should keep in mind that because of the correlation between the control and the instruments collinearity reduces the precision of the IV estimates. In any case, though, the inclusion of the control does not eliminate or reduce the size and significance of the college externality and it does not change the insignificance of the high school externality at all. Using the initial or final distribution of skills to calculate the constant composition of wages (specifications 2 and 5 ) or restricting the sample to male only (specifications 3 and 6 ) do not produce significant changes in the estimates.

In a second set of equations, reported in Table 10, we control for the impact of initial sector composition on productivity growth by state. Using data on Gross State Product by sector 1963-1997 (from the Bureau of Economic Analysis) and merging them with employment data from the Census 1960 to 2000, we calculate the output per worker in 41 industries (identical to those used above based on Hanson and Slaughter 2002) in 1960, 1970, 1980, 1990 and $2000^{22}$. Then we calculate the share of state gross product in 1960 accounted for by the top $10 \%, 20 \%$ and $50 \%$ most productive sectors. We interact these shares with the productivity growth of those industries over each of the following decades and include the resulting variables as controls in Table 10 (third row). The presence of a large initial share of highly productive industries may induce high TFP growth in a state, particularly in decades when productivity growth of those industries is large (hence the interaction). The possibility that such demand-driven productivity growth attracts highly educated workers may induce omitted variable bias in the regressions. Table 10 shows the OLS (columns 1-3) and IV estimates (columns 4-6) of the externalities when we control for this demand-driven productivity growth. The correlation between this type of growth and the increase in college education (and with the immigration-based IV) is small (never larger than 0.2) and the OLS and IV estimates are not very different. The IV estimates of the college externalities are between 5 and $6 \%$ and the high school externalities are never higher than $0.5 \%$. We also constructed the demand-driven TFP growth using the sectors with the highest share of college graduates (rather than labor

\footnotetext{
${ }^{22}$ We use GSP in 1963 to proxy GSP in 1960 and that in 1997 to proxy 2000 GSP.
} 
productivity) in 1960. The regression including those controls (not reported here) gives estimates of college and high school externalities virtually identical to those in Table 10.

\section{Conclusions}

This paper analyzes the connection between years of high school per worker, years of college per worker and TFP using a new model and a new empirical strategy. Assuming the existence of two types of technology (traditional and modern) with more educated workers having a comparative advantage in the modern sector, we gain new insights into the effects of a shift in educational attainments on total factor productivity. The nature of the technology is such that below a certain schooling level (estimated to be around 12 years of schooling) increases in schooling have low private as well as social returns because the technology used has low returns to skills and does not allow for the production of differentiated goods. Above that threshold, however, higher education has large private and social returns as the modern technology results in the increased variety of goods produced and hence overall TFP gains. Using parameters calibrated to the 1980 distribution of schooling attainments, a good proxy for the 1960-2000 average, the model shows that the increase in secondary education had very small effects on TFP (less than 1\% for an increase of one year in high school per worker) while the increase in college education had external effects between 5 and $9 \%$. Using compulsory attendance and child labor laws as instruments for years of high school per worker and proximity to Land Grant Colleges and nationality-based immigration of college graduates as instruments for years of college per worker across U.S. states, we are able to empirically estimate these effects. The empirics confirm the insignificant external effect of increased high school education and large positive effects of increased college education on TFP. Let us emphasize that the empirical strategy used allows us to identify externalities localized within states only, while nation-wide externalities of schooling (operating through institutions or common technological adoption) cannot be captured in this framework. Both the model and empirical results reinforce, complement and elaborate on previous findings on human capital externalities such as Acemoglu and Angrist (2001), Moretti (2004) and Ciccone and Peri (2006).

\section{References}

Acemoglu D. (1998) "Why Do New Technologies Complement Skills? Directed Technical Change and Wage Inequality" Quarterly Journal of Economics, 113, pp. 1055-1090.

Acemoglu D. (2002) "Directed Technical Change." Review of Economic Studies, 69(4), pp. 781-810.

Acemoglu D. and Angrist J. (2001) "How Large are the Social Returns to Education: Evidence from Compulsory Schooling Laws," in Ben Bernanke and Kenneth Rogoff (Editors), NBER Macroeconomic Annual 2000, pp 9-59. 
Acemoglu D. and F. Zilibotti (2001) "Productivity Differences" Quarterly Journal of Economics, 116 pp. 563606.

Angrist J. (1995), "The Economic Returns to Schooling in the West Bank and Gaza Strip," American Economic Review 85, pp.1065-1087.

Autor, D., L. Katz and A. Krueger (1998) "Computing Inequality: Have Computers Changed te Labor Market?" Quarterly Journal of Economics,113, pp. 1169-1213.

Autor D. , L. Katz and M. Kearny (2007) "Trends in U.S. Wage Inequality, Revising the Revisionists" Mimeo MIT, March 2007. 96 (3). pp. 499-522.

Broda, C. and Weinstein D. (2006) "Globalization and the Gains from Variety" Quarterly Journal of Economics 121(2), pages 541-585.

Bureau of Labor Statistics (2005) "Current Expenditure Shares Tables" available at http://www.bls.gov/cex/home.htm\#tables.

Card D. (1993) "Using Geographic Variation in College Proximity to estimate the Returns to Schooling " NBER Working Paper \# 4483.

Card, D. (2001) "Immigrant Inflows, Native Outflows, and the Local labor Market Impacts of Higher Immigration" Journal of Labor Economics, 19(1), pp. 22-64.

Caselli F. and W. J. Coleman, (2002) "The U.S. Technology Frontier." American Economic Review, P\&P, 92(2), pp. 148-152.

Caselli F. and W. J. Coleman, (2006) "The World Technology Frontier.", American Economic Review, 96 (3). pp. 499-522.

Ciccone A. and G. Peri (2005) "'Long-Run Substitutability between More and Less Educated Workers: Evidence from U.S. States 1950-1990" Review of Economics and Statistic, 87 (4), pp. 652-663.

Ciccone A. and G. Peri (2006) "Identifying Human Capital Externalities: Theory with Applications", Review of Economic Studies, 73, pp. 381-412.

Cortes P. (2006) "The Effect of Low-Skilled Immigration on U.S. Prices: Evidence from CPI data" Mimeo University of Chicago, November 2006.

Currie J. and E. Moretti (2003) "Mother's Education and the Intergenerational Transmission of Human Capital: Evidence from College Openings " Quarterly Journal of Economics 118(4) pp.1495-1532. 
De la Fuente A. and R. Domenech, (2001) "Schooling Data, Technical Diffusion, and the Neoclassical Model." American Economic Review Papers and Proceedings, 90(5), pp. 323-327.

De la Fuente A. and R. Domenech, (2006) "”Human Capital in Growth Regressions: How Much Difference Does Data Quality Make." Journal of the European Economic Association, 4 (1), pp. 1-36..

Hall R. and C.. I. Jones (1999) "Why do Some countries produce so much More Output Per worker than Others"? Quarterly Journal of Economics, 114(1) pp. 83-116.

Hanson G. and M. Slaughter (2002) "Labor Market Adjustments in Open Economies: Evidence from US States" Journal of International Economics, 57 (1) pp.3-29.

Katz L. and K. Murphy (1992) "Changes in Relative Wages 1963-1987- Supply and Demand Factors," Quarterly Journal of Economics 107 (1), pp. 35-78.

Lewis E. (2004) "Local Open Economies within the U.S.. How do Industries respond to Immigration?" Federal Reserve Bank of Philadelphia, Working Paper 04-1.

Milligan K., E. Moretti and P. Oreopoulos (2004) "Does Education Improve Citizenship? Evidence from the U.S. and the U.K." Journal of Public Economics 88 (9), pp.1667-1695

Moretti E. (2004) "Estimating the Social Return to Higher Education: Evidence from Longitudinal and Repeated Cross-Sectional Data," Journal of Econometrics 121 (1), pp. 175-212.

Moretti E. and L. Lochner (2004) "The Effect of Education on Criminal Activity: Evidence from Prison Inmates, Arrests and Self-Report" American Economic Review 94(1), pp.155-189.

Ottaviano G. and G. Peri (2005) "Rethinking the Gains from Immigration: Theory and Evidence from the U.S." NBER Working Paper, 11672.

Oreopoulos P., M. Page and A. Stevens (2006) "Does Human Capital Transfer from Parent to Child? The Intergenerational Effects of Compulsory Schooling" , Journal of Labor Economics, 24(4), pp. 729-760.

Park, Jin Huem (1994) "Estimation of Sheepskin Effects and Returns to Schooling Using the Old and New CPS Measures of Educational Attainment", Princeton University Industrial Relation Section, Working Paper No. 338.

Rauch J. (1993) " "Productivity Gains from Geographic Concentration in Cities," Journal of Urban Economics 34 , pp. $380-400$. 
Ruggles Steven, Matthew Sobek, Trent Alexander, Catherine A. Fitch, Ronald Goeken, Patricia Kelly Hall, Miriam King, and Chad Ronnander. Integrated Public Use Microdata Series: Version 3.0 [Machinereadable database]. Minneapolis, MN: Minnesota Population Center [producer and distributor], 2005. http://www.ipums.org.

Temple J. (1999) "The New Growth Evidence." Journal of Economic Literature, 37(1), pp. 112-156.

U.S. Bureau of Census (2000) "County and City Data Book" 2000 Edition on CD ROM

Woolridge J.L. (2002), "Econometric Analysis of Cross Section and Panel Data", (Boston, MA: MIT Press, 2001).

Yeaple S.(2005) " A Simple model of Firm Heterogeneity, international trade and Wages" Journal of International Economics, 65 pp. 1-20. 


\section{Appendix 1: Details of the Model with Trade}

Consumers in each state can demand varieties of $X$ produced in their state or the other; $x_{j i}$ denotes the demand from state $i$ of a variety produced in state $j$. Each state produces a continuum of varieties, between $\left[0, N_{1}\right]$ for state 1 and $\left[0, N_{2}\right]$ for state 2 . The demands for local and imported varieties are respectively:

$$
\begin{aligned}
x_{i i} & =\left(\frac{s\left(P_{X i}\right)}{P_{X i}}\right)\left(\frac{p_{i}}{P_{X i}}\right)^{-\sigma} E_{i} \quad i=1,2 \\
x_{j i} & =\left(\frac{s\left(P_{X i}\right)}{P_{X i}}\right)\left(\frac{p_{j} . \tau}{P_{X i}}\right)^{-\sigma} E_{i} \quad i, j=1,2 \quad i \neq j
\end{aligned}
$$

where $p_{i}$ is the price of varieties produced and sold in state $i$, while the price paid for imported varieties equals $p_{j}$. . $s\left(P_{X i}\right)$ is the share of aggregate expenditure devoted to purchase good $X$ in state $i$ and is given by an expression similar to (3). $E_{i}$ is aggregate expenditure; its value is as (8) and can be pinned down by the assumption of balanced trade between the two states. The price for the composite good $X$ in state $i$ is now given by:

$$
P_{X i}=\left[N_{i} p_{i}{ }^{1-\sigma}+N_{j}\left(p_{j} \cdot \tau\right)^{1-\sigma}\right]^{\frac{1}{1-\sigma}}, \quad i, j=1,2 \quad i \neq j
$$

The wage schedule in each state has the qualitative features of (7) and the thresholds $\bar{Z}_{1}$ and $\bar{Z}_{2}$ differ between states whenever their skill distributions $G_{i}(Z)$ are different.

On the production side, profit maximization and free entry in sector $X$ yield prices for the varieties produced in each state and for the size of firms in a manner similar to (16). The only difference is that now the quantity of each variety produced in state $i$ equals the sum of the local and foreign demands:

$$
x_{i}=x_{i i}+x_{i j}=(\sigma-1) F_{X} \quad i, j=1,2 \quad i \neq j
$$

In the symmetric equilibrium the number of firms (varieties) in each state is proportional to the size of its highly skilled group as in (18).

As before, the thresholds $\bar{Z}_{1}$ and $\bar{Z}_{2}$ are pinned down from the market clearing conditions. There are now three sets of market-clearing conditions: one for the homogeneous good $Y$, one for each variety of $X$ produced in state 1 and one for each variety of $X$ produced in state $2 .{ }^{23}$ The market clearing conditions relative to good $X$ are:

$$
\begin{aligned}
& s\left(P_{X 1}\right) \bar{W}_{1}\left(\frac{p_{1}^{1-\sigma}(v)}{P_{X 1}^{1-\sigma}}\right)+s\left(P_{X 2}\right) \bar{W}_{2}\left(\frac{\left(p_{1}(v) \cdot \tau\right)^{1-\sigma}}{P_{X 2}^{1-\sigma}}\right)=x_{1}(v) p_{1}(v) \quad v \in\left[0, N_{1}\right] \\
& s\left(P_{X 1}\right) \bar{W}_{1}\left(\frac{\left(p_{2}(\eta) \cdot \tau\right)^{1-\sigma}}{P_{X 1}^{1-\sigma}}\right)+s\left(P_{X 2}\right) \bar{W}_{2}\left(\frac{p_{2}^{1-\sigma}(\eta)}{P_{X 2}^{1-\sigma}}\right)=x_{2}(\eta) p_{2}(\eta) \quad \eta \in\left[0, N_{2}\right]
\end{aligned}
$$

\footnotetext{
${ }^{23}$ By Walras' law and because of balanced trade one of them is redundant.
} 
Let's define $\vartheta_{i i}$ and $\vartheta_{j i}$ as the shares of the expenditure on good $X$ that consumers in state $i$ devote to local and imported varieties respectively:

$$
\vartheta_{i i}=\frac{N_{i} p_{i}^{1-\sigma}}{P_{X i}^{1-\sigma}} \quad \vartheta_{j i}=\frac{N_{j}\left(\tau p_{j}\right)^{1-\sigma}}{P_{X i}^{1-\sigma}} \quad \text { with } i \neq j
$$

Substituting for $\bar{W}_{1}, \bar{W}_{2}, p_{1}, p_{2}, N_{1}$ and $N_{2}$ and using the notation for the effective supply of highly and low educated workers, $\bar{A}_{i}^{H} H_{i}$ and $\bar{A}_{i}^{L} L_{i}$, we can re-write (31) as they appear in (23) in the main text.

\section{Appendix 2: Empirical Wage Schedule and Schooling Distribution}

The model described in section 2 has three important implications for the wage schedule. First, the returns to schooling for low education levels (the slope of the wage schedule) should be lower than for high education levels (see Figure 1). Second, rather than a general convexity of the wage schedule, our model predicts a well localized kink in the $(\log )$ wage schedule (again, see Figure 1). Third, skill-biased technological change in this model takes the form of an increase in the difference between $g_{X}$ and $g_{Y}$. Panel 1 shows the estimated wage schedule, using U.S. census micro-data for the years 1960 to 2000 (IPUMS, Ruggles et al., 2005); specifically, we use the 1\% sample for 1960 and 1970 and the 5\% sample for 1980, 1990 and 2000. We regress the log real weekly wages (yearly wages divided by number of weeks worked during the last year) on the usual individual controls (sex, race, place of birth and marital status dummies and a quartic polynomial in experience), and on years of schooling dummies. The sample is made up of individuals between 16 and 65 years of age who worked at least one week in the previous year, earned some wage income and did not live in group quarters. The regression is estimated separately for each census year. For the 1960-80 period we can estimate a specific return for each yearly attainment (as the schooling data report the highest grade attended) while for 1990 and 2000 we convert the categorical variables provided into years of schooling using the conversion table available in Park (1994) and we estimate returns only for those attainments. Panel 1 reports the estimated value for the schooling dummies on the vertical axis against years of schooling on the horizontal axis. What is apparent from the reported wage schedules is that from 1970, and increasingly over time, the returns to schooling below 12 years (high school graduation) have been lower than the returns to schooling above 12 years. Interestingly, the kink in the wage schedule ( $\bar{Z}$ in our model) appears to be around 12 years of schooling (high school graduation) in each census year, and the skill-biased technological change of the 1980s and 1990s has taken the form of a higher $g_{X}$. If we estimate linear returns to schooling allowing for a different slope below and above 12 years we obtain significantly different estimates for each census year (including 1960) and overwhelmingly so since 1970. These features provide a direct confirmation of the validity of our model and allow us to estimate $g_{X}$ and $g_{Y}$, and to calibrate $F_{X}$ in order to obtain a value of $\bar{Z}$ equivalent to 12 years. As $g_{X}$ and $g_{Y}$ change across censuses 
we use their median values (equal to the value in 1980) which are $g_{X}=1.6$ and $g_{Y}=0.4$ corresponding to a $2 \%$ return to schooling below 12 years and $8 \%$ return above 12 years.

The distribution of workers' skills, $G(Z)$, is captured by a 5-cell histogram in which we discretize the continuous variable $Z \in[0,1]$ into years of schooling, re-scaling the maximum achievable years (20, assuming that a Ph.D. degree requires, on average, 4 years) to equal 1. The point $Z=0.6$ (i.e. 12/20) represents high school graduation and the point $Z=0.8$ (i.e. 16/20) represents college graduation. The other two boundaries of the histogram are $Z=0.4$ (primary school) and $Z=0.65,13$ years of schooling (college dropout). Our simulations assume an initial distribution of schooling across groups that matches the 1980 census, and then test the robustness of our results using 1960 as the initial distribution. The initial density function for $Z$ (at time $t_{0}=1980$ ) is computed by converting Table 1 values for 1980 into densities. For instance, the proportion of middle school dropouts with education level between 0 and 0.4 is 0.08 , which implies a density of 0.2 (such that $(0.4-0) \times 0.2=0.08)$, and so on. The schooling density function is thus given by:

$$
\phi(Z)\left\{\begin{array}{c}
0.2 \text { for } 0 \leq Z<0.4 \\
0.7 \text { for } 0.4 \leq Z<0.6 \\
7.8 \text { for } 0.6 \leq Z<0.65 \\
1.33 \text { for } 0.65 \leq Z<0.8 \\
0.95 \text { for } 0.8 \leq Z \leq 1
\end{array}\right\}
$$


Figures

Figure 1

The log wage schedule as a function of individual skills

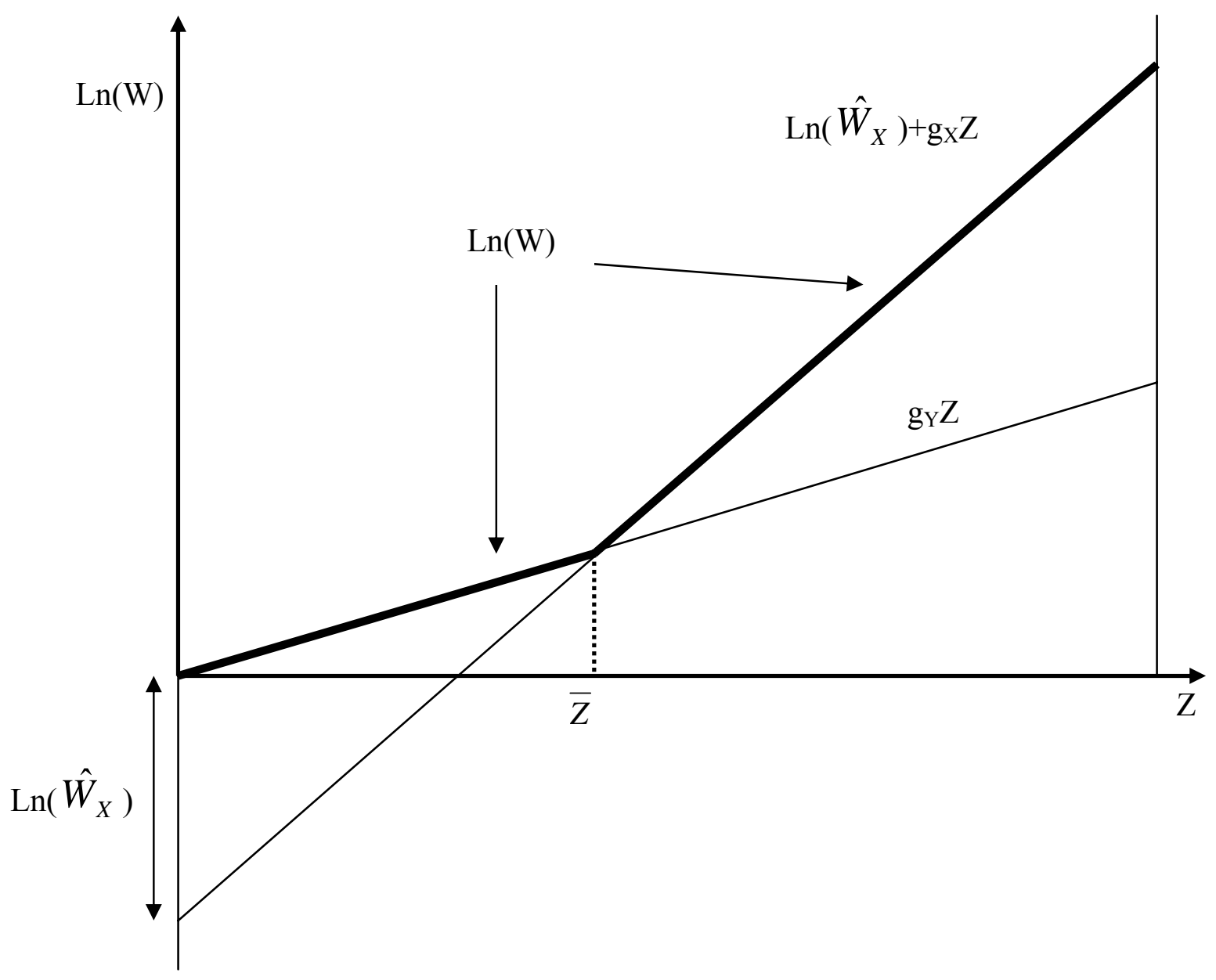


Figure 2:

TFP changes and changes in years of high school per worker

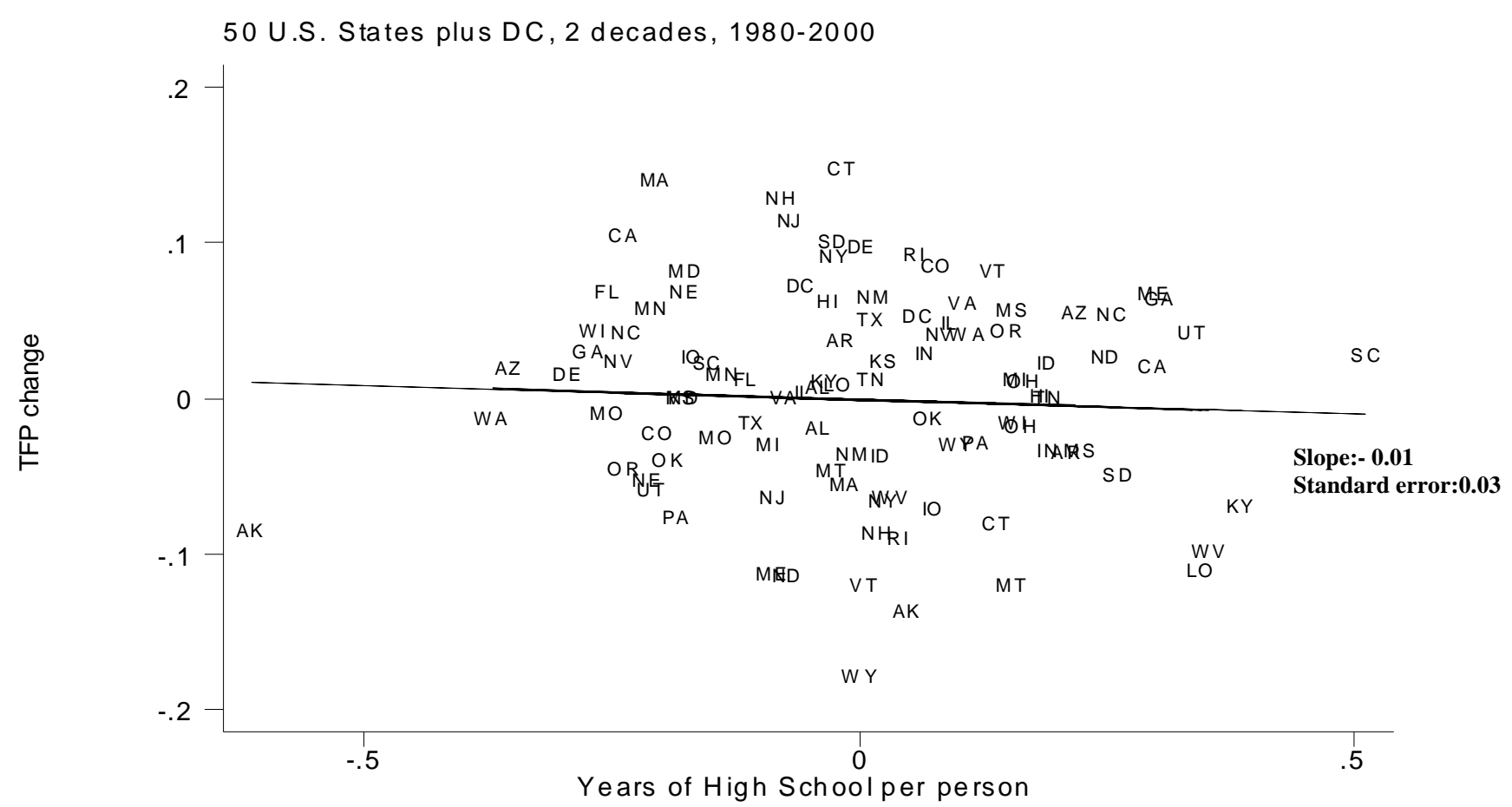

Figure 3:

TFP changes and changes in years of college per worker

50 U.S. States plus DC, 2 decades, 1980-2000

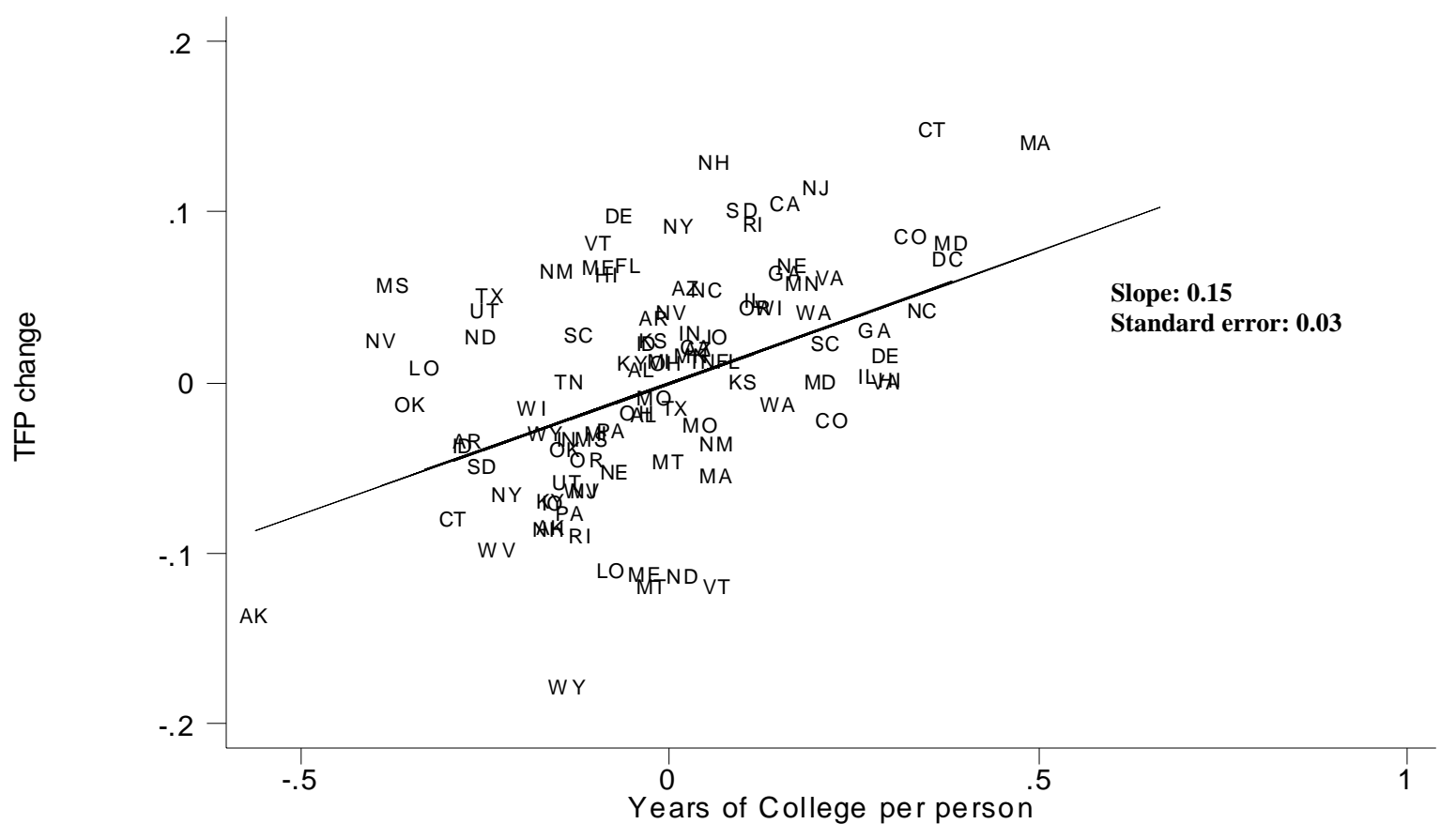


Figure 4:

Predictive power of the imputed share of high school dropout immigrants in total employment on the actual share of high school dropout immigrants

50 U.S. States, 4 decades 1960-2000

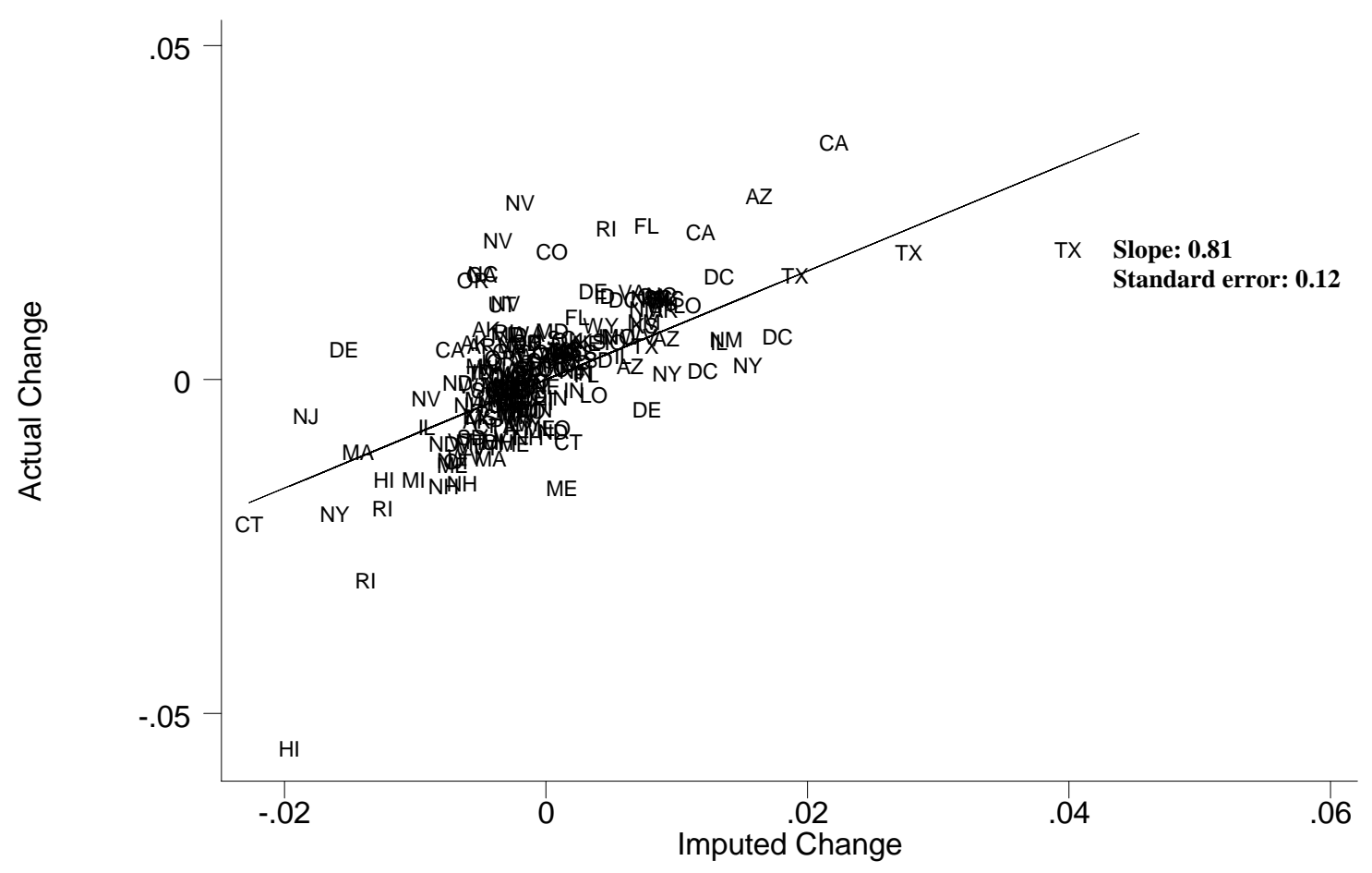

Figure 5

Predictive power of the imputed share of college educated immigrants in total employment on the actual share of college educated immigrants 50 U.S. States, 4 decades 1960-2000

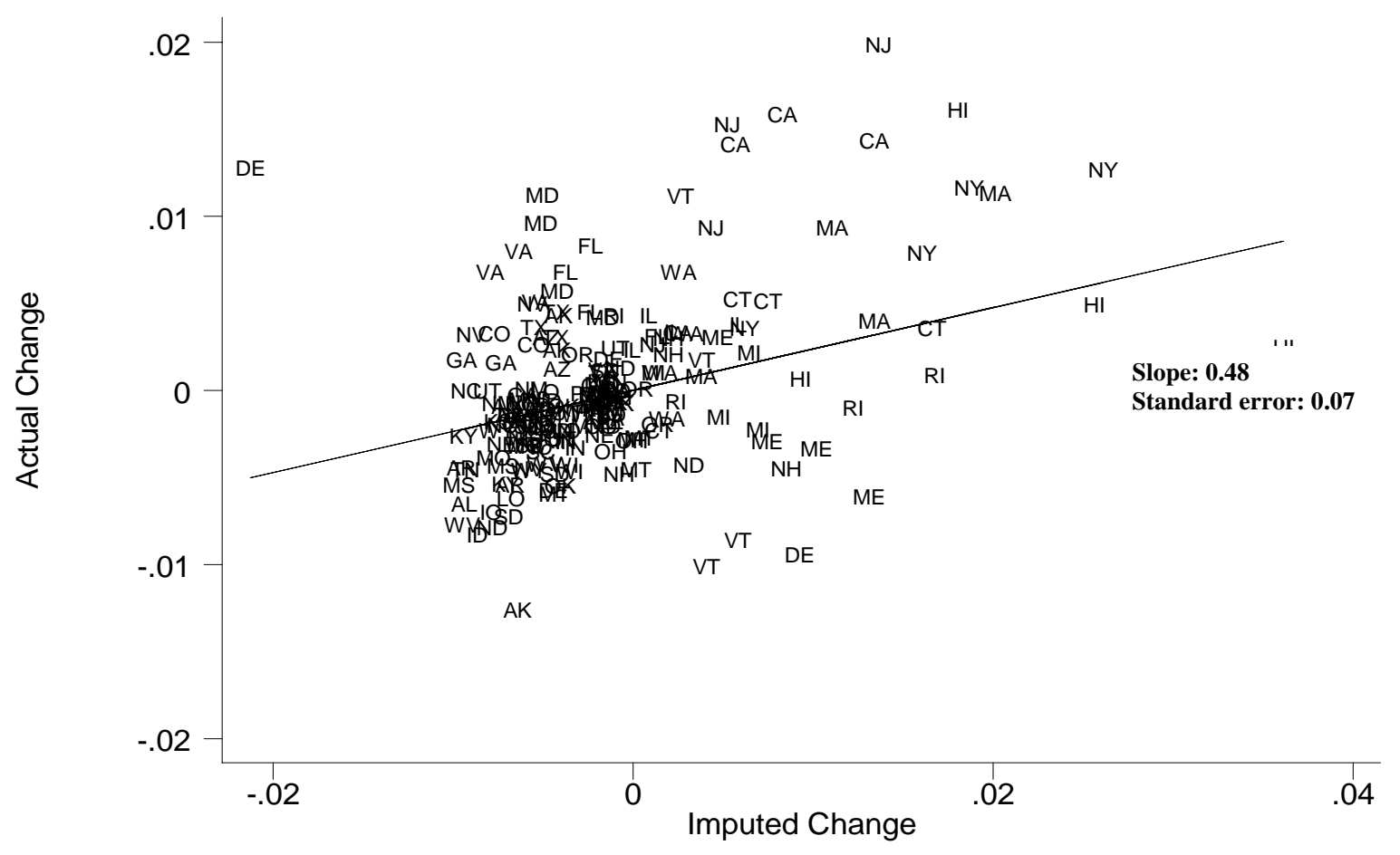


Panel 1:

Log wage schedules 1960-2000

Returns to schooling in 1960

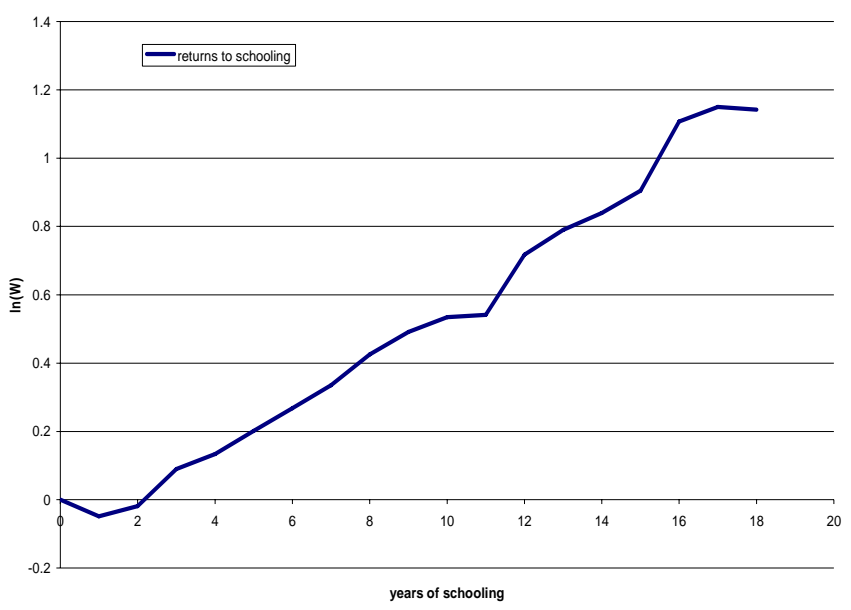

Returns to schooling in 1980

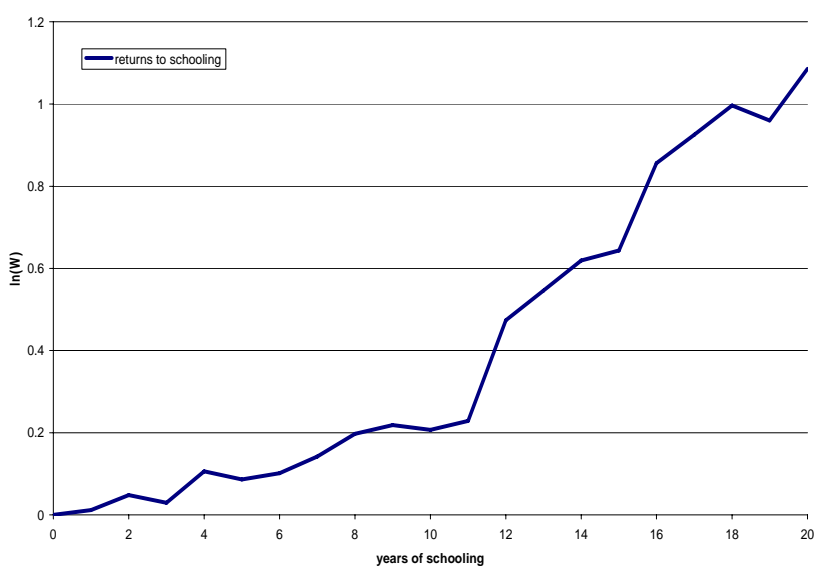

Returns to schooling in 1970
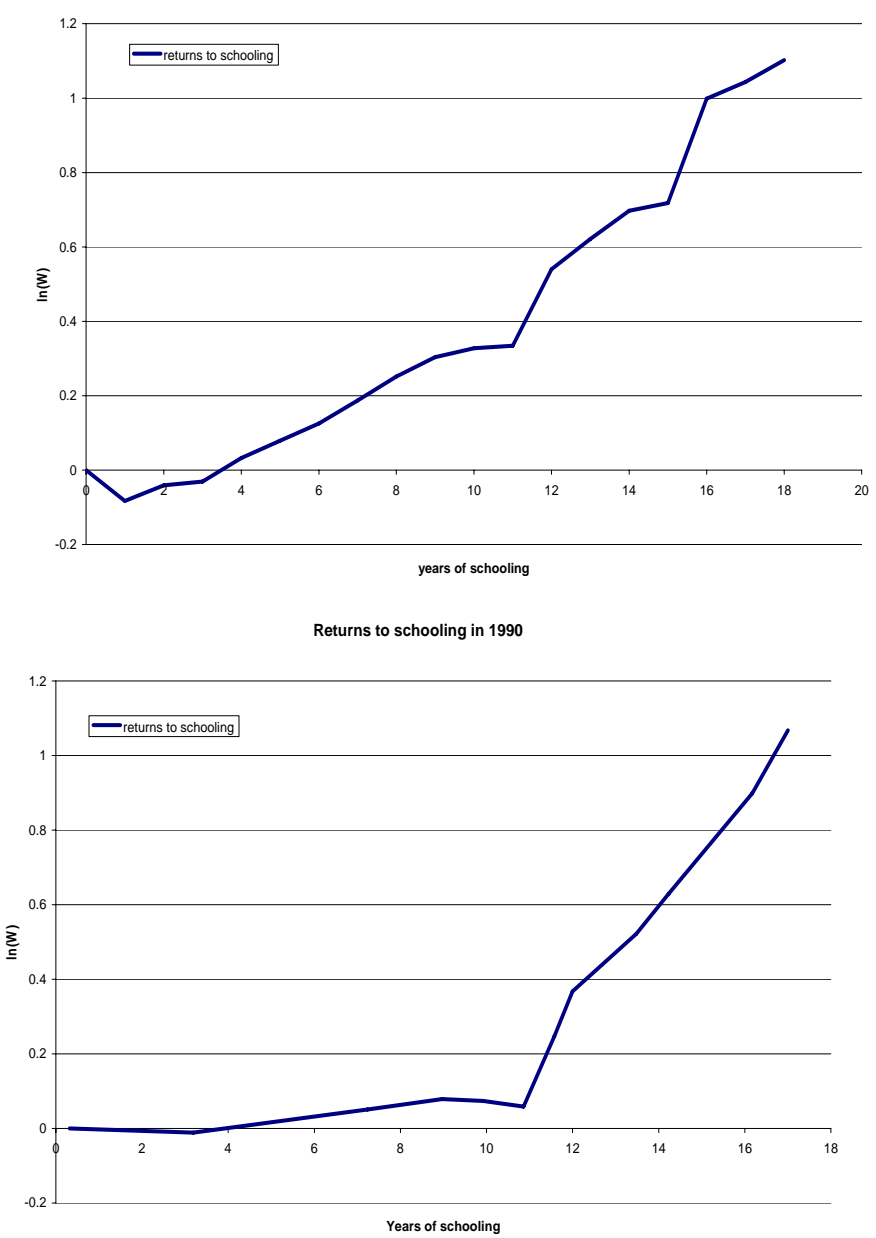

Returns to schooling in 2000

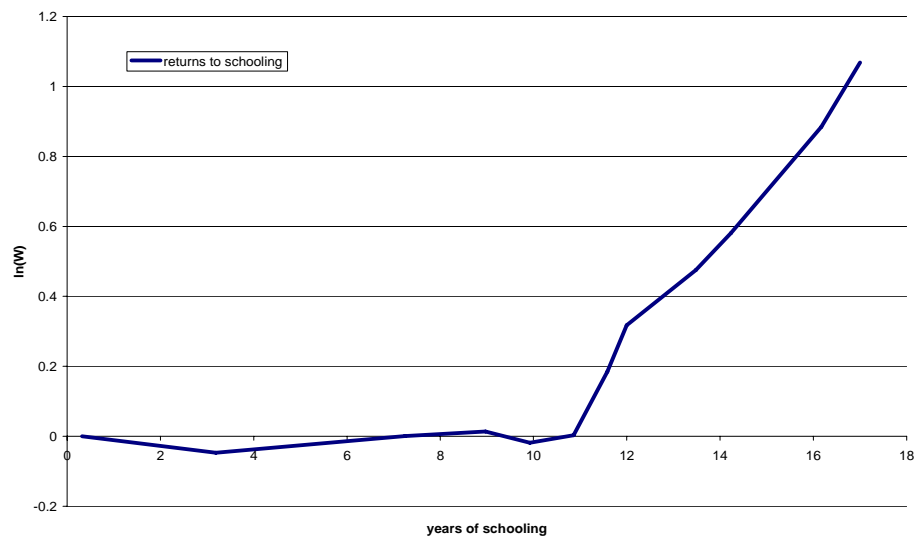

Note: Each graph reports the logarithm of the real weekly wage against years of schooling. These returns to years of schooling are the estimated coefficients obtained by regressing for each Census year the log weekly wages on years of schooling dummies and an additional set of individual controls. We included individuals between 16 and 65 years of age who worked at least one week in the previous year, earned some wage income and did not live in group quarters. 
Table 1:

Shares of workers in each of the 5 schooling attainment groups and average schooling, Aggregate US, 1960-2000

\begin{tabular}{l|rrrrr}
\hline Group: & $\mathbf{1 9 6 0}$ & $\mathbf{1 9 7 0}$ & $\mathbf{1 9 8 0}$ & $\mathbf{1 9 9 0}$ & $\mathbf{2 0 0 0}$ \\
\hline Less than 8 years, Middle School Dropouts & 0.28 & 0.16 & 0.08 & 0.04 & 0.04 \\
Between 8 and 11 years, High School Dropouts & 0.22 & 0.20 & 0.14 & 0.12 & 0.11 \\
12 years, High School Graduates & 0.30 & 0.37 & 0.39 & 0.31 & 0.28 \\
Between 13 and 15 years, College Dropouts & 0.10 & 0.13 & 0.20 & 0.30 & 0.32 \\
More than 16, College Graduates & 0.10 & 0.13 & 0.19 & 0.23 & 0.25 \\
Average years of schooling & 10.65 & 11.56 & 12.64 & 13.11 & 13.22 \\
\hline
\end{tabular}

Source: Authors' calculations based on IPUMS data. Workers are individuals between 16 and 65 years of age who worked at least one week in the previous year, earned some wage income and did not live in group quarters. 
Table 2

Simulated effects of increased secondary attendance and increased college graduation on TFP

\begin{tabular}{|c|c|c|c|c|c|c|}
\hline & \multirow{2}{*}{$\begin{array}{c}\begin{array}{c}\text { Model with } \\
\text { perfect } \\
\text { competition }\end{array} \\
\text { No trade }\end{array}$} & \multicolumn{3}{|c|}{$\begin{array}{l}\text { Model with monopolistic } \\
\text { competition }\end{array}$} & \multicolumn{2}{|c|}{$\begin{array}{l}\text { Model with monopolistic } \\
\text { competition } \\
\text { and higher returns to high skills } \\
\end{array}$} \\
\hline & & No trade & Costly Trade & Costly Trade & $\begin{array}{l}\text { Costly Trade } \\
\text { Same initial } \\
\text { composition }\end{array}$ & $\begin{array}{l}\text { Costly Trade } \\
\text { Different initial } \\
\text { composition }\end{array}$ \\
\hline & (1) & (2) & (3) & (4) & (5) & (6) \\
\hline \multicolumn{7}{|l|}{$\begin{array}{l}\text { \%Change in TFP as a consequence of } \\
\text { one extra year of schooling due to } \\
\text { increasing secondary attendance }\end{array}$} \\
\hline $\begin{array}{l}\% \text { Change in TFP as a consequence of } \\
\text { one extra year of schooling due to an } \\
\text { increase in college graduation }\end{array}$ & $0 \%$ & $8.90 \%$ & $3.25 \%$ & $5.34 \%$ & $7.90 \%$ & $7.45 \%$ \\
\hline \multicolumn{7}{|l|}{$\begin{array}{l}\text { (Externality from } \\
\text { College)/(Externality from High }\end{array}$} \\
\hline Returns to schooling, $g_{X}, g_{Y}$ & $\begin{array}{l}g_{X}=1.6 \\
g_{Y}=0.4\end{array}$ & $\begin{array}{l}g_{X}=1.6 \\
g_{Y=0.4}\end{array}$ & $\begin{array}{l}g_{X}=1.6 \\
g_{Y=0.4}\end{array}$ & $\begin{array}{l}g_{X}=1.6 \\
g_{Y=0.4} \\
\end{array}$ & $\begin{array}{l}g_{X}=2.7 \\
g_{Y=0.4}\end{array}$ & $\begin{array}{l}g_{X}=2.7 \\
g_{Y}=0.4\end{array}$ \\
\hline Trade costs, $\tau$ & $\tau=\infty$ & $\tau=\infty$ & $\tau=1.5$ & $\tau=2$ & $\tau=2$ & $\tau=2$ \\
\hline \multicolumn{7}{|c|}{$\begin{array}{l}\text { The values of the remaining parameters used in the simulations are: } \theta=1.5, \sigma=2, \beta=0.65, F_{X} \text { is calibrated as to produce the initial value of } \bar{Z} \text { around } 12 \\
\text { years of schooling, and the initial distribution of schooling is as that in } 1980 \text {. } \\
\text { Column (1) reports the simulated TFP effects from increased schooling in a model with perfect competition in both sectors X and Y. Column ( } 2 \text { ) reports } \\
\text { the TFP effects of increased schooling in a model with monopolistic competition in sector X and no trade between the two states. Columns ( } 3 \text { ) and (4) } \\
\text { report the localized TFP effects of increased schooling in a model with monopolistic competition in sector X and costly trade. These effects are } \\
\text { constructed as the difference between the TFP effects in the state where schooling increased and the TFP effects in the other state (diffused externality). } \\
\text { The iceberg transport costs are set equal to } \tau=1.5 \text { and } \tau=2 \text { respectively. The simulation in column (5) is similar to that in column (4) except for a value of } \\
g_{X}=2.7 \text {. The simulation in Column (6) considers states with different initial distributions between more and less educated workers with the rest of the } \\
\text { parameter values as in (5). In particular, the state experiencing the increase in schooling is assumed to have a distribution of schooling similar to the U.S. } \\
\text { state whose average schooling in } 1980 \text { was one standard deviation above the national average (Montana) while the distribution of schooling for the other } \\
\text { state corresponds to the U.S. state whose average schooling in } 1980 \text { was one standard deviation below the national average (Rhode Island). }\end{array}$} \\
\hline
\end{tabular}


Table 3:

Correlations between TFP changes and changes in years of high school and years of college per worker: US States, 1960-2000

\begin{tabular}{|c|c|c|c|c|c|c|}
\hline Specifications & $\begin{array}{c}\text { (1) } \\
\text { Basic 1960- } \\
2000\end{array}$ & $\begin{array}{c}(2) \\
\text { With regional } \\
\text { dummies }\end{array}$ & $\begin{array}{c}(3) \\
1970- \\
2000\end{array}$ & $\begin{array}{c}(4) \\
1980- \\
2000\end{array}$ & $\begin{array}{c}(5) \\
\text { Omitting } \\
\text { California }\end{array}$ & $\begin{array}{c}(6) \\
\text { US-born white } \\
\text { males only }\end{array}$ \\
\hline$\overline{\Delta s c h o o l}_{s t}^{H S}$ & $\begin{array}{c}0.013 \\
(0.014)\end{array}$ & $\begin{array}{c}0.022 \\
(0.014)\end{array}$ & $\begin{array}{c}0.034 \\
(0.020)\end{array}$ & $\begin{array}{c}0.01 \\
(0.03)\end{array}$ & $\begin{array}{c}0.026 \\
(0.018)\end{array}$ & $\begin{array}{c}0.024 \\
(0.014)\end{array}$ \\
\hline $\begin{array}{c}\Delta \overline{\text { school }}_{s t}^{C O L L} \\
\mathbf{R}^{2}\end{array}$ & $\begin{array}{c}0.069 * * \\
(0.02) \\
0.72\end{array}$ & $\begin{array}{c}0.087 * * \\
(0.02) \\
0.74\end{array}$ & $\begin{array}{c}0.104 * * \\
(0.03) \\
0.70\end{array}$ & $\begin{array}{c}0.156^{* *} \\
(0.03) \\
0.71\end{array}$ & $\begin{array}{c}0.090 * * \\
(0.029) \\
0.74\end{array}$ & $\begin{array}{c}0.084 * * \\
(0.025) \\
0.64\end{array}$ \\
\hline $\begin{array}{c}\text { Number of } \\
\text { Observations }\end{array}$ & 204 & 204 & 153 & 102 & 200 & 204 \\
\hline
\end{tabular}

Dependent variable: The percentage TFP change by state and decade as measured by the change in the cleaned constant composition real average wage, $\Delta \ln \omega_{\text {st }}^{\text {cc }}$, calculated as described in the main text. Method of estimation: least squares with each observation weighted by the employment in the state-year. Columns (1), (2) and (6) report the results of regressions on a panel of 50 US states plus DC over 4 decades 1960-2000. Specifications (3), (4) and (5) use a subset-of years or omit states as described in the column header. Fixed census year effects are included in all regressions. In specification (2) three regional dummies (East, South, Mid-west, omitting West) are included. Heteroskedasticity-robust standard errors, clustered by state are reported in parentheses.

$* *$ indicate a coefficient that is significant at the $5 \%$ confidence level. 
Table 4:

First-stage regressions: Effect of child-labor (CL) and compulsory-attendance (CA) laws on years of high school per worker, share of high school dropouts and years of college per worker

\begin{tabular}{|c|c|c|c|c|c|c|}
\hline \multirow{2}{*}{$\begin{array}{c}\text { Dependent Variable: } \\
\text { Specification: }\end{array}$} & \multicolumn{2}{|c|}{$\begin{array}{c}\text { Years of High School per } \\
\text { worker }\end{array}$} & \multicolumn{2}{|c|}{$\begin{array}{c}\text { Share of workers without } \\
\text { high school degree }\end{array}$} & \multicolumn{2}{|c|}{$\begin{array}{c}\text { Years of College per } \\
\text { worker }\end{array}$} \\
\hline & (1) & (2) & (3) & (4) & (5) & (6) \\
\hline Share $\mathrm{CA}<\mathbf{8}$ & $\begin{array}{c}-1.17 * * \\
(0.47)\end{array}$ & $\begin{array}{l}-0.51 \\
(0.43)\end{array}$ & $\begin{array}{l}0.14 * * \\
(0.03)\end{array}$ & $\begin{array}{l}0.09^{* *} \\
(0.03)\end{array}$ & $\begin{array}{l}-0.60 \\
(0.37)\end{array}$ & $\begin{array}{l}-0.45 \\
(0.37)\end{array}$ \\
\hline Share CA $>11$ & $\begin{array}{l}1.19 * * \\
(0.35)\end{array}$ & $\begin{array}{l}1.04 * * \\
(0.34)\end{array}$ & $\begin{array}{c}-0.07 * * \\
(0.02)\end{array}$ & $\begin{array}{c}-0.05 * * \\
(0.02)\end{array}$ & $\begin{array}{l}-0.43 \\
(0.29)\end{array}$ & $\begin{array}{l}-0.53 \\
(0.29)\end{array}$ \\
\hline Share $\mathrm{CL}<6$ & $\begin{array}{c}-1.31^{* *} \\
(0.58)\end{array}$ & $\begin{array}{l}-0.86 \\
(0.52)\end{array}$ & $\begin{array}{l}0.13 * * \\
(0.04)\end{array}$ & $\begin{array}{c}0.09 * * \\
(0.04)\end{array}$ & $\begin{array}{c}0.23 \\
(0.43)\end{array}$ & $\begin{array}{c}0.29 \\
(0.43)\end{array}$ \\
\hline Share $\mathbf{C L}>9$ & $\begin{array}{l}0.81 * * \\
(0.30)\end{array}$ & $\begin{array}{c}0.42 * * \\
(0.28)\end{array}$ & $\begin{array}{c}-0.08 * * \\
(0.02)\end{array}$ & $\begin{array}{c}-0.05 * * \\
(0.02)\end{array}$ & $\begin{array}{c}0.43 \\
(0.27)\end{array}$ & $\begin{array}{c}0.37 \\
(0.27)\end{array}$ \\
\hline $\begin{array}{c}\text { Region-specific } \\
\text { Effects } \\
\text { F-Test of Joint }\end{array}$ & No & Yes & No & Yes & No & Yes \\
\hline $\begin{array}{c}\text { Significance } \\
\text { (p-value) }^{\mathrm{a}}\end{array}$ & $\begin{array}{c}9.84 \\
(0.000) \\
\end{array}$ & $\begin{array}{c}6.52 \\
(0.0001) \\
\end{array}$ & $\begin{array}{c}13.5 \\
(0.0000) \\
\end{array}$ & $\begin{array}{c}5.06 \\
(0.0007) \\
\end{array}$ & $\begin{array}{c}2.8 \\
(0.03)\end{array}$ & $\begin{array}{c}2.4 \\
(0.05) \\
\end{array}$ \\
\hline $\mathbf{R}^{2}$ & 0.89 & 0.91 & 0.89 & 0.91 & 0.51 & 0.60 \\
\hline Observations & 204 & 204 & 204 & 204 & 204 & 204 \\
\hline
\end{tabular}

All regressions are in differences and they include decade fixed effects. Each column is a separate regression. Units of observations are 50 U.S. states plus D.C. over the period 1960-2000. Method of estimation: least squares with each observation weighted by the employment in the state-year. Heteroskedasticity-robust standard errors clustered by state are in parentheses

** indicate a coefficient that is significant at the $5 \%$ confidence level.

a: Null hypothesis is that the explanatory variables have no power in predicting the dependent variable. The p-value is the confidence level at which the null hypothesis is rejected. 
Table 5:

First-stage regressions: Effect of the presence of Land Grant colleges on years of college per worker, share of college graduates and years of high school per worker

\begin{tabular}{|c|c|c|c|}
\hline Dependent Variable & $\begin{array}{l}\text { (1) } \\
\begin{array}{c}\text { Change in the share of } \\
\text { college graduates in } \\
\text { employment }\end{array}\end{array}$ & $\begin{array}{l}(2) \\
\text { Change in years of } \\
\text { college per worker }\end{array}$ & $\begin{array}{l}\text { (3) } \\
\text { Change in years of high } \\
\text { school per worker }\end{array}$ \\
\hline $\begin{array}{c}\text { People living within } 100 \mathrm{~km} \text { of a } \\
\text { Land Grant college as \% of labor force, } \\
1970\end{array}$ & $\begin{array}{l}0.18^{*} \\
(0.10)\end{array}$ & $\begin{array}{l}3.11^{*} \\
(1.70)\end{array}$ & $\begin{array}{l}3.40^{*} \\
(2.05)\end{array}$ \\
\hline $\begin{array}{l}\text { People living within } 100 \mathrm{~km} \text { of a } \\
\text { Land Grant college as \% of labor force, } \\
1980\end{array}$ & $\begin{array}{l}0.18 * \\
(0.10)\end{array}$ & $\begin{array}{l}3.04 * \\
(1.71)\end{array}$ & $\begin{array}{l}2.40 * \\
(1.20)\end{array}$ \\
\hline $\begin{array}{c}\text { People living within } 100 \mathrm{~km} \text { of a } \\
\text { Land Grant college as \% of labor force, } \\
1990\end{array}$ & $\begin{array}{c}0.27 * * \\
(0.09)\end{array}$ & $\begin{array}{c}4.62 * * \\
(1.51)\end{array}$ & $\begin{array}{c}-2.40 \\
(1.81)\end{array}$ \\
\hline $\begin{array}{c}\text { F-Test of Significance } \\
(p-\text {-value })^{\mathbf{a}}\end{array}$ & $\begin{array}{c}6.99 \\
(0.0001)\end{array}$ & $\begin{array}{c}6.91 \\
(0.0001)\end{array}$ & $\begin{array}{c}6.16 \\
(0.0001)\end{array}$ \\
\hline $\mathbf{R}^{2}$ & 0.72 & 0.71 & 0.80 \\
\hline Observations & 153 & 153 & 153 \\
\hline
\end{tabular}

All regressions include state and year fixed effects. Each column is a separate regression. 50 U.S. states plus D.C. are included over three decades from 1970 to 2000 . Method of estimation: least squares with each observation weighted by the employment in the state-year. Heteroskedasticity robust standard errors clustered by state are in parentheses.

$*$, ** indicate coefficients significant at the $10 \%, 5 \%$ confidence level.

a: Null hypothesis is that the explanatory variables have no power in predicting the dependent variable. The p-value is the confidence level at which the null hypothesis is rejected. 
Table 6:

First-stage regressions:

Impact of imputed college-educated immigrants on years of college per worker, share of college graduates and years of high school per worker

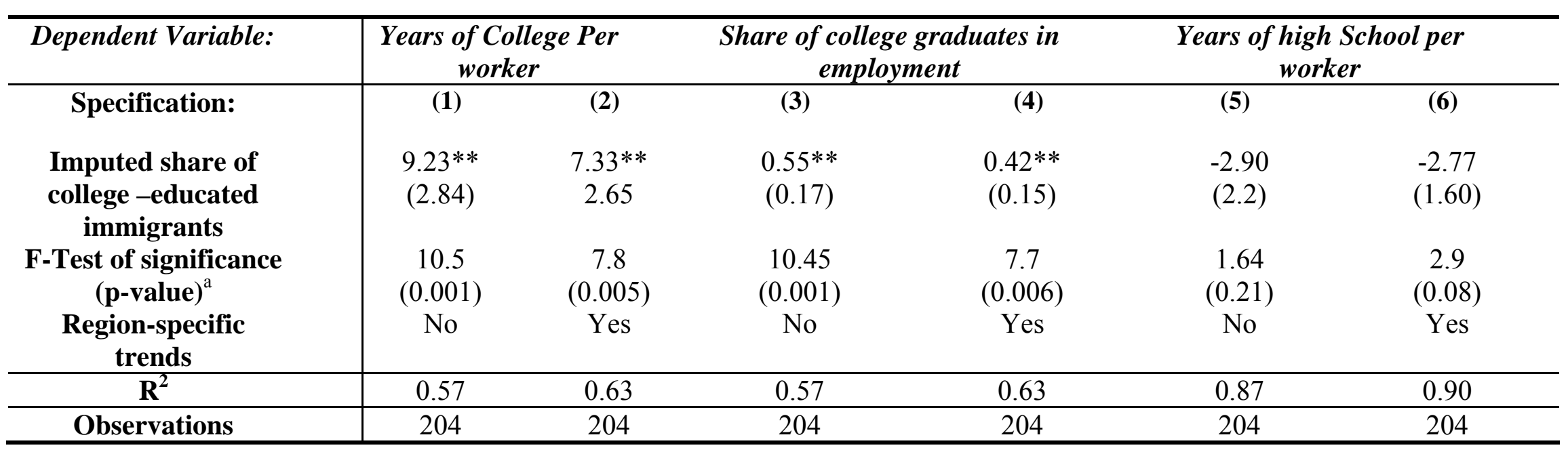

All regressions in differences over decades and include decade fixed effects. Each column is a separate regression. 50 U.S. states plus D.C. included over the period 1960-2000. Method of estimation: least squares with each observation weighted by the employment in the state-year. Heteroskedasticity robust standard errors are in parentheses.

** indicate a coefficient that is significant at the $5 \%$ confidence level.

a: Null hypothesis is that the explanatory variables have no power in predicting the dependent variable. The p-value is the confidence level at which the null hypothesis is rejected. 
Table 7:

Imputed instruments for college-educated immigrants and less educated immigrants: comparisons and power

\begin{tabular}{c|cc}
\hline Dependent Variable: & $\begin{array}{c}\text { Actual share of workers with } \\
\text { college education } \\
(\mathbf{1})\end{array}$ & $\begin{array}{c}\text { Actual share of workers with no high } \\
\text { school diploma } \\
\text { (2) }\end{array}$ \\
\hline $\begin{array}{c}\text { Imputed share of foreign-born } \\
\text { college educated }\end{array}$ & $0.55^{* *}$ \\
$\begin{array}{c}\text { Imputed share of foreign-born } \\
\text { with no high school diploma }\end{array}$ & $(0.17)$ & $0.64^{* *}$ \\
F-test & 10.4 & $15)$ \\
$\quad \mathbf{R}^{2}$ & 0.57 & 0.87 \\
$\begin{array}{c}\text { Ratio: (standard deviation actual } \\
\text { share)/(standard deviation imputed } \\
\text { share of foreign-born) } \\
\text { Changes 1960-2000 } \\
\text { Observations }\end{array}$ & $(0.021 / 0.011)=1.9$ & $(0.06 / 0.01)=6$ \\
\hline
\end{tabular}

Note: The first column reports the OLS coefficient, F-test and $\mathrm{R}^{2}$ of the regression of the decade-changes in the share of college educated across 51 states over the period 1960-2000 on the imputed share of foreign-born college educated. The imputation is done based on the 1960 distribution of foreign-born by countries of birth across US states. We attribute to each nationality in each state its average composition across schooling groups in the US in 1960, then we augment the group of college-educated by nationality and state in each decade with the national growth rate of college educated from that country of origin. The second column reports the OLS coefficient, F-test and $\mathrm{R}^{2}$ of the same regression for high school dropouts. On the fifth row we report the ratio of the standard deviation of imputed and actual changes in the share of college educated and high school dropouts across states.

** indicate a coefficient that is significant at the $5 \%$ confidence level. 
Table 8:

2SLS estimates of the effects of years of high school and years of college on TFP All instrumental variables included

\begin{tabular}{|c|c|c|c|c|c|c|}
\hline Specification: & $\begin{array}{c}\text { (1) } \\
\text { Basic }\end{array}$ & $\begin{array}{c}(2) \\
\text { Final } \\
\text { composition }\end{array}$ & $\begin{array}{c}\text { (3) } \\
\text { Male only }\end{array}$ & $\begin{array}{c}(4) \\
\text { Omitting } \\
\text { California }\end{array}$ & $\begin{array}{c}(5) \\
1980-2000\end{array}$ & $\begin{array}{c}(6) \\
1970-1990\end{array}$ \\
\hline $\begin{array}{c}\Delta \overline{\text { school }}_{s t}^{H S} \\
\Delta \overline{\text { school }}_{s t}^{C O L L}\end{array}$ & $\begin{array}{l}-0.01 \\
(0.01) \\
0.06^{* *} \\
(0.025)\end{array}$ & $\begin{array}{c}-0.01 \\
(0.01) \\
0.055^{* *} \\
(0.025)\end{array}$ & $\begin{array}{c}0.01 \\
(0.015) \\
0.05^{* *} \\
(0.025)\end{array}$ & $\begin{array}{c}0.01 \\
(0.02) \\
0.05^{* *} \\
(0.025)\end{array}$ & $\begin{array}{l}0.01 \\
(0.03) \\
0.12 * * \\
(0.04)\end{array}$ & $\begin{array}{l}-0.01 \\
(0.03) \\
0.12 * * \\
(0.03)\end{array}$ \\
\hline $\begin{array}{c}\text { Test of over-identifying } \\
\text { restrictions } \\
\text { (p-value of a Chi-square with } 6 \\
\text { degrees of freedom) }\end{array}$ & $\begin{array}{l}8.82 \\
(0.19)\end{array}$ & $\begin{array}{l}8.80 \\
(0.20)\end{array}$ & $\begin{array}{c}7.6 \\
(0.27)\end{array}$ & $\begin{array}{r}7.35 \\
(0.29)\end{array}$ & $\begin{array}{r}3.92 \\
(0.70)\end{array}$ & $\begin{array}{l}8.82 \\
(0.19)\end{array}$ \\
\hline $\mathbf{R}^{2}$ & 0.68 & 0.71 & 0.45 & 0.69 & 0.49 & 0.33 \\
\hline Observations & 153 & 153 & 153 & 150 & 102 & 102 \\
\hline
\end{tabular}

Note: Dependent variable is the percentage TFP change by state and decade as measured by the cleaned constant composition real wage change $\Delta \ln \omega_{\text {st }}^{\text {cc }}$ calculated as described in the main text. Each column reports estimates from a separate regression. All regressions include decade dummies. The observations correspond to state-decade changes between 1970 and 2000 . Heteroskedasticity-robust standard errors, clustered by state are in parentheses. The method of estimation is 2SLS with each observation weighted by the employment in the state-year. We use as instrumental variables the imputed share of college-educated immigrants, the population share near a Land-Grant college and CA-CL laws, as described in the main text. Specification (1) is the basic specification comparable to specification (1) of Table 3, Specification (2) calculates the cleaned constant composition real wage change $\Delta \ln \omega^{\mathrm{cc}}{ }_{\mathrm{s}}$ for fixed composition at the end (rather than at the beginning) of the decade. Specification (3) includes only male workers in the construction of the constant composition wage, specification (4) omits the observations relative to California, Specification (5) includes only the decade-changes between 1980 and 2000, while (6) includes only the changes in the 1970 and 1990 period.

** indicate a coefficient that is significant at the $5 \%$ confidence level. 
Table 9:

Controlling for changes in human capital driven by initial sector-composition

\begin{tabular}{|c|c|c|c|c|c|c|}
\hline Dependent Variable: & \multicolumn{3}{|c|}{$O L S$} & \multicolumn{3}{|c|}{ IV, with all Instruments } \\
\hline Specification: & $\begin{array}{c}\text { (1) } \\
\text { Basic }\end{array}$ & $\begin{array}{c}(2) \\
\text { Final composition }\end{array}$ & $\begin{array}{c}\text { (3) } \\
\text { Male only }\end{array}$ & $\begin{array}{c}(4) \\
\text { Basic }\end{array}$ & $\begin{array}{c}(5) \\
\text { Final } \\
\text { composition }\end{array}$ & $\begin{array}{c}\text { (6) } \\
\text { Male only }\end{array}$ \\
\hline$\Delta \overline{\text { school }}_{s t}^{H S}$ & $\begin{array}{c}0.013 \\
(0.013)\end{array}$ & $\begin{array}{l}0.013 \\
(0.02)\end{array}$ & $\begin{array}{c}0.025 \\
(0.015)\end{array}$ & $\begin{array}{l}-0.01 \\
(0.02)\end{array}$ & $\begin{array}{c}0.01 \\
(0.02)\end{array}$ & $\begin{array}{l}0.005 \\
(0.01)\end{array}$ \\
\hline$\Delta \overline{\text { school }}_{\text {st }}^{C O L L}$ & $\begin{array}{l}0.06 * * \\
(0.025)\end{array}$ & $\begin{array}{l}0.06 * * \\
(0.028)\end{array}$ & $\begin{array}{l}0.062 * * \\
(0.020)\end{array}$ & $\begin{array}{l}0.11^{* *} \\
(0.04)\end{array}$ & $\begin{array}{l}0.09 * * \\
(0.045)\end{array}$ & $\begin{array}{l}0.11 * * \\
(0.04)\end{array}$ \\
\hline $\begin{array}{l}\text { Change in the share of } \\
\text { college graduates driven } \\
\text { by initial sector- } \\
\text { composition }\end{array}$ & $\begin{array}{c}1.4 \\
(0.8)\end{array}$ & $\begin{array}{l}1.1 \\
(1.0)\end{array}$ & $\begin{array}{c}0.70 \\
(1.02)\end{array}$ & $\begin{array}{c}1.4 \\
(2.2)\end{array}$ & $\begin{array}{l}1.0 \\
(1.8)\end{array}$ & $\begin{array}{c}2.2 \\
(1.8)\end{array}$ \\
\hline Observations & 204 & 204 & 204 & 153 & 153 & 153 \\
\hline
\end{tabular}

Note: Dependent variable is the percentage TFP change by state and decade as measured by the cleaned constant composition real wage change $\Delta \ln \omega_{\text {st }}^{\text {cc }}$ calculated as described in the main text. All regressions include decade dummies. The observations correspond to statedecade changes. Heteroskedasticity-robust standard errors are in parentheses. The method of estimation for columns (1)-(3) is OLS including decade fixed effects, with each observation weighted by the employment in the state-year and standard errors are clustered by state. The period included is 1960-2000. Columns (4)-(6) are estimated using 2SLS estimation technique with each observation weighted by the employment in the state-year. As instrumental variables we include the imputed share of college-educated immigrants, the population share near a Land-Grant college and CA-CL laws, as described in the main text. The period included is 1970-2000.

** indicate a coefficient that is significant at the $5 \%$ confidence level. 
Table 10:

Controlling for productivity growth driven by initial sector-composition

\begin{tabular}{|c|c|c|c|c|c|c|}
\hline Dependent & \multicolumn{3}{|c|}{ OLS } & \multicolumn{3}{|c|}{ IV, with all Instruments } \\
\hline Specification: & $\begin{array}{c}\text { (1) } \\
\text { Control based } \\
\text { on top } 10 \% \text { most } \\
\text { productive } \\
\text { sectors }\end{array}$ & $\begin{array}{c}\text { (2) } \\
\text { Control based } \\
\text { on top } 20 \% \\
\text { most productive } \\
\text { sectors }\end{array}$ & $\begin{array}{c}(3) \\
\text { Control based on } \\
\text { top } 50 \% \text { most } \\
\text { productive } \\
\text { sectors }\end{array}$ & $\begin{array}{c}\text { (4) } \\
\text { Control based } \\
\text { on top } 10 \% \\
\text { most productive } \\
\text { sectors }\end{array}$ & $\begin{array}{c}\text { (5) } \\
\text { Control based on } \\
\text { top 20\% most } \\
\text { productive sectors }\end{array}$ & $\begin{array}{c}\text { (6) } \\
\text { Control based on } \\
\text { top } 50 \% \text { most } \\
\text { productive sectors }\end{array}$ \\
\hline$\overline{\mathrm{school}}_{s t}^{H S}$ & $\begin{array}{c}0.016 \\
(0.011)\end{array}$ & $\begin{array}{c}0.02 \\
(0.011)\end{array}$ & $\begin{array}{c}0.016 \\
(0.023)\end{array}$ & $\begin{array}{r}-0.005 \\
(0.02)\end{array}$ & $\begin{array}{l}0.005 \\
(0.02)\end{array}$ & $\begin{array}{c}0.005 \\
(0.025)\end{array}$ \\
\hline$\Delta \overline{\text { school }}_{s t}^{C O L L}$ & $\begin{array}{l}0.06^{* *} \\
(0.025)\end{array}$ & $\begin{array}{c}0.055^{* *} \\
(0.025)\end{array}$ & $\begin{array}{r}0.066^{* *} \\
(0.021)\end{array}$ & $\begin{array}{c}0.05 \\
(0.027)\end{array}$ & $\begin{array}{l}0.050^{*} \\
(0.028)\end{array}$ & $\begin{array}{l}0.048^{* * *} \\
(0.024)\end{array}$ \\
\hline $\begin{array}{l}\text { (Share of gross } \\
\text { state product in } \\
\text { top productive } \\
\text { sectors, 1960)X } \\
\text { (productivity } \\
\text { growth of } \\
\text { sectors) }\end{array}$ & $\begin{array}{c}4.3 \\
(4.1)\end{array}$ & $\begin{array}{c}2.3 \\
(1.6)\end{array}$ & $\begin{array}{c}0.55 \\
(0.33)\end{array}$ & $\begin{array}{c}3.4 \\
(4.2)\end{array}$ & $\begin{array}{c}2.5 \\
(1.5)\end{array}$ & $\begin{array}{c}0.60 * * \\
(0.31)\end{array}$ \\
\hline Observations & 204 & 204 & 204 & 153 & 153 & 153 \\
\hline
\end{tabular}

Note: Dependent variable is the percentage TFP change by state and decade as measured by the cleaned constant composition real wage change $\Delta \ln \omega^{c c}$ st calculated as described in the main text. The observations correspond to state-decade changes and are weighted by the state employment. Heteroskedasticity-robust standard errors are in parentheses. The method of estimation for columns (1)-(3) is OLS including decade fixed effects, with each observation weighted by the employment in the state-year and standard errors are clustered by state. The period included is 1960-2000. Columns (4)-(6) are estimated using 2SLS estimation technique with each observation weighted by the employment in the state-year. We include as instrumental variables the imputed share of college-educated immigrants, the population share near Land-Grant colleges and CA-CL laws, as described in the main text. The period included is 1970-2000.

** indicate a coefficient that is significant at the $5 \%$ confidence level. 
